\title{
The decoration of the Danila Bible: ANICONISM AS ROYAL IDEOLOGY IN NINTH-CENTURY IBERIA
}

\author{
JESÚS RODRÍGUEZ VIEJO ${ }^{1}$ \\ University of Aberdeen
}

Recibido: 11 de abril de 2019

Aceptado: 4 de septiembre de 2019

\begin{abstract}
The so-called Danila Bible (Cava dei Tirreni, Biblioteca della Badia, Ms. 1) is the earliest surviving manuscript created in the early medieval Iberian Peninsula displaying a cohesive decorative programme of figurative nature. Although its exact provenance has been matter of extensive discussion, current research points to the northern Kingdom of Asturias during the reign of King Alfonso II (791-842). The decoration of this monumental bible displays a complex aniconic programme made of decorated initials, frontispieces, and other symbols, such a number of crosses and cross-shaped motifs of large dimensions and different forms. This study aims to analyse in particular the different nature of these cross-shaped motifs displayed in the Danila Bible. This research also intends to shed light on the reception of aniconism in the Kingdom of Asturias, as well as its Visigothic background, one century after the Islamic conquest of 711 and in the wake of the First Iconoclasm and the Council of Frankfurt.
\end{abstract}

\section{Keywords}

Manuscript, patronage, Asturias, Pre-Romanesque, aniconism.

\section{Resumen}

La llamada Biblia de Danila (Cava dei Tirreni, Biblioteca della Badia, Ms. 1) es el ejemplo preservado más antiguo de manuscrito miniado con un programa decorativo coherente creado en la Península Ibérica altomedieval. La teoría más aceptada hoy en día apunta al Reino de Asturias durante el próspero mandato de Alfonso II (791-842). Los folios de este manuscrito monumental contienen un programa de motivos decorativos entre los cuales destacan una serie de símbolos en forma de cruz de grandes dimensiones. Este artículo analiza especialmente las representaciones en forma de cruz de la biblia, explorando también la recepción de pensamiento anicónico en el norte de España aproximadamente un siglo después de la conquista árabe, sus raíces visigodas, así como las posibles influencias del periodo de la Iconoclastia bizantina y el Concilio carolingio de Fráncfort.

\section{Palabras clave}

Manuscrito, patrocinio, Asturias, Prerrománico, aniconismo.

1 University of Aberdeen. Correo electrónico: s07jr9@abdn.ac.uk. ORCID: https://orcid.org/0000-00032744-0279. I am indebted to my former mentor at the University of Oviedo, Prof. Lorenzo Arias Páramo, who facilitated the publication of this article by kindly allowing me to use some of the images of this undervalued manuscript, still not digitised. 


\section{Résumé}

La Bible dite de Danila (Cava dei Tirreni, Biblioteca della Badia, Ms. 1) est le plus ancien exemple connu de manuscrit enluminé dans la Péninsule Ibérique au Haut Moyen Âge qui soit doté d'un programme décoratif cohérent. L'hypothèse la plus répandue l'assigne au royaume des Asturies et le date du règne d'Alphonse II (791-842). Les folios de ce manuscrit monumental contiennent un programme de motifs décoratifs dont des symboles en forme de croix de grande dimension. Dans cet article, on analysera plus précisément ces représentations et on évaluera la réception de la pensée aniconique dans le nord de la Péninsule, un siècle après la conquête arabe, leurs éventuelles racines wisigothiques, ainsi que de possibles influences de l'iconoclasme byzanthin et du concile carolingien de Francfort.

\section{Mots-clés}

Manuscrit, patronage, Asturies, Préroman, aniconisme.

In 2010, amidst an unprecedented media covering, a facsimile edition of the so-called Danila Bible was presented to the public in Oviedo ${ }^{2}$. This event culminated the first comprehensive research project on this large early medieval manuscript, an object barely known today in Spain. The reason for this peculiar cirscumstance is perhaps geographical. The manuscript has been preserved since the early thirteenth century in the southern Italian Abbey of Cava dei Tirreni, near the city of Salerno ${ }^{3}$. The sometimes called "Visigothic Bible of Cava" or the "Cava Bible" is nonetheless one of the earliest examples of pictorial arts of early medieval Spain ${ }^{4}$.

The most widely accepted theory today says that the Danila Bible was made at some point in the first decades of the ninth century by a scriptorium attached to the figure of the Asturian monarch, King Alfonso II (752-842) . The monumental manuscript, made of 303 folios, whose pages measure an average of $36 \times 26 \mathrm{~cm}$, does not display a single full-page scene or initial depicting the human figure. The bible exhibits instead a myriad of small initials with animal, vegetal, and geometric patterns and motifs, as well as a

\footnotetext{
2 Paolo Cherubini, José Antonio Valdes Gallego, Alfonso Garcia Leal, La Biblia de Danila (Codex Biblicus, Ms. 1 de la abadía de la Santísima Trinidad de Cava dei Tirreni), ed. GEA, Oviedo, 2010. Jerrilynn DodDs (dir.), The Art of Medieval Spain, A.D. 500-1200 (Catalogue of the homonym exhibition held at the Metropolitan Museum of Art, November 18, 1993 - March 13, 1994), ed. Metropolitan Museum of Art, New York, 1993, pp. 150-151. See also Manuel C. DíAz y DíAz, Códices visigóticos en la monarquía leonesa, Centro de Estudios e Investigación "San Isidoro", León, 1983, pp. 251-253, 286, 292, $300-303$. E. A. Lowe, Palaeographical Papers 1907-1965, vol. I, ed. Clarendon Press, Oxford, 1972, pp. 335-341. 3 Mario Rotili, La miniatura de la Badia di Cava. II. Le racolte di miniature italiane e straniere, ed. Di Mauro, Naples, 1977. Vito Lore, Monasteri, principi, aristocrazie. La Trinità di Cava nel secoli XI e XII, ed. CISAM, Spoleto, 2008.

4 Roger Collins, The Arab conquest of Spain, 711-797, ed. Blackwell, Oxford, 1989, pp. 7-11. Thomas GLIck, Cristianos y musulmanes en la España medieval (711-1250), ed. Alianza, Madrid, 2000, pp. 23-43. Pedro Chalmeta, Invasión e islamización. La sumisión de Hispania y la formación de al-Andalus, ed. Mapfre, Madrid, 1994.

5 Luis Araujo-Costa, "La literatura en tiempo de Alfonso II el Casto", Estudios sobre la monarquía asturiana (Colección de trabajos realizados con motivo del XI centenario de Alfonso II el Casto, celebrado en 1942), Antonio Ballesteros (dir.), ed. Real Instituto de Estudios Asturiano, Oviedo, 1949, pp. 363-416. Manuel Diaz y Diaz, Asturias en el siglo VIII. La cultura literaria, ed. Sueve, Oviedo, 2001.
} 
number of cross-shaped symbols, sometimes occupying the entirety of the page. Most of the academic interest in the object, especially from Italian and Spanish specialists, has been focused on the manuscript's textual contents and its provenance. From an art historical perspective, however, the Danila Bible and its decoration have never been properly discussed. This research aims to become a first in-depth analysis of the most prominent decorative motifs displayed in this unique manuscript. Particular attention will be given to the several cross-shaped motifs, a symbol of fundamental importance in the ideological thought of a period defined by fierce cross-religious confrontation, heresy, and constant official debates about belief, cult, and representation.

The 711 Islamic conquest of the Iberian Peninsula was followed almost instantly by the collapse of the ancient Visigothic kingdom, its court, and the old social structures that had dominated the Iberian landscape since the fall of the Roman Empire. The Kingdom of Asturias was the first Christian entity to independently assume a political role in the mountainous northwest of the peninsula. To their background, a combination of fleeing Romanized Visigothic elites and a native northern Spanish Celtic stratum, a paramount element was added - the Christian faith ${ }^{6}$. Heirs of the Visigothic political tradition of Toledo, the Asturian kings rapidly chose the Cross as a state symbol and as a visual embodiment of their aspirations to restore the former glory of the Visigothic kingdom and its zealous Christian kings, face to what they considered their Islamic nemesis ${ }^{7}$.

The relatively isolated region of Asturias flourished for nearly two centuries, roughly between the second quarter of the eighth and the first decades of the tenth century ${ }^{8}$. Architectural history, both religious and civil, is the field that has attracted most of the the attention of academic experts. These buildings are arguably the most impressive remains of the kingdom and of the wider European pre-Romanesque movements. The originality of this Asturian style has deserved the well-known fascination that Spanish authors and academics from abroad, such as Helmut Schlunk, Georgiana King, Achim Arbeiter, Antonio Bonet Correa, Lorenzo Arias Páramo, or César García de Castro Valdés, have showed since the early twentieth century to this day ${ }^{9}$. Sculpture, though,

\footnotetext{
6 Luis Agustín Garcia Moreno, Historia de la España visigoda, ed. Cátedra, Madrid, 2008, pp. 170-190. Robert Dykes Shaw, "The fall of the Visigothic power in Spain”, English Historical Review, 21 (1926), pp. 209-228. Pierre Riche, "Les refugiés wisigoths dans le monde caroligien”, L'Europe héritière de l'Espagne wisigothique, Jacques Fontaine, Christine Pellistrandi, (eds.), ed. CNRS, Paris, 1992, pp. 177-183. Luis Agustín Garcia Moreno, El fin del reino visigodo de Toledo: decadencia y catástrofe, una contribución a su crítica, ed. Aldecoa, Madrid, 1975.

7 Bernard Bischoff, "Kreuz und Buch im Frühmittelalter und in den ersten Jahrhundernten der spanischen Reconquista", Bibliotheca docet. Festgabe für Carl Wehner, Joost Siegfried (ed.), ed. Erasmus Buchhandlung, Amsterdam, 1963, pp. 16-34.

8 Arbeiter, Noack-Haley, "The Kingdom of Asturias", pp. 112-119. Louis Barrau-Dihigo, Historia política del reino asturiano (718-910), ed. Cañada, Gijon, 1989, pp. 103-115. Jose Ignacio RuIz DE LA Peña Solar, La monarquía asturiana (718-910), ed. Ayuntamiento de Cangas de Onís, Cangas de Onis, 2000, pp. 13-42. Demetrio Mansilla, "La supuesta metrópoli de Oviedo", Hispania Sacra, 8 (1955), pp. 259-274. Paulino García Toraño, Historia del reino de Asturias, ed. Gráficas Summa, Oviedo, 1986.

9 Antonio Bonet Correa, Spanish pre-Romanesque art, ed. New York Graphic Society, Greenwich, 1968. Georgiana KInG, Pre-Romanesque churches of Spain, ed. Bryn Mawr College Press, 1924. A more recent
} 
is remarkably boor and the remains of pictorial arts, probably with the only exception of the frescos of San Julián de los Prados (Santullano), are few in quantity, scattered, and most of them, severely damaged too.

As these frescos in particular show, state-sponsored Asturian painting of religious nature was very likely aniconic in nature. Much has been said on that score ${ }^{10}$. Complex geometric motifs of Roman origin were extensively used in most buildings and were certainly combined with urban landscapes of a style that many have compared to Pompeian taste, at least in a particularly important setting such as at San Julián itself ${ }^{11}$. Modern studies on Asturian pictorial arts have traditionally lagged behind the most advanced state of research concerning architecture. The recent work by Lorenzo Arias Páramo has, however, condensed all the available knowledge on the wall painting of the Asturian kingdom, attracting both public and academic attention ${ }^{12}$.

Despite its enormous historical importance as one of the earliest medieval Spanish manuscripts still preserved, the Danila Bible is largely unknown today in Spain. With the sole exception of Ayuso Marazuela's 1956 work, studies by Italian, French, and German specialists have been predominant throughout the twentieth century ${ }^{13}$. Its presence in Italy has certainly motivated fundamental studies in that country as one of Europe's earliest and largest medieval manuscripts ${ }^{14}$. However, due to the lack of narrative figuration and the fine work of round Visigothic writing (combined with Roman uncial and semi-uncial sections) that the manuscript displays, all the studies in Italian that have dealt with the bible have analyzed exclusively its textual content, the features of its writing and, more globally, bible copying in the Early Middle Ages. Be that as it may, the images displayed in the manuscript, including rich geometric patterns, animal motifs, and the crosses that are the foci of this research, have been largely set aside by a modern scholarship mostly made of palaeographers and codicologists.

In this regard, the very first attempt to describe the decoration of the Danila Bible has been made by Alfonso García Leal, chair and professor of Latin at the University of

\footnotetext{
introduction in English is to be found in: Kenneth J. Conant, Carolingian and Romanesque Architecture, ed. Yale University Press, New Haven, 1992, pp. 93-100.

10 Helmut Schlunk, Magin Berenguer, La pintura mural asturiana de los siglos IX y X, ed. L. Sánchez Cuesta, Oviedo, 1957, pp. 95-105, 161-167.

11 Isidro BANGo ToRviso, "La cultura artística de la monarquía astur: la última manifestación de la Antigüedad, Astures. Pueblos y culturas en la frontera del Imperio Romano, Isidro Bango Torviso (ed.), ed. Asociación Astures: Gran Enciclopedia Asturiana, Gijón, 1995, pp. 183-186.

12 Lorenzo Arias Paramo, La pintura mural en el reino de Asturias en los siglos IX y X, ed. Librería Cervantes. Oviedo, 1999.

13 Teófilo Ayuso-Marazuela, La biblia visigótica de la Cava dei Tirreni, ed. CSIC, Madrid, 1956. May Vieillard-Troiekouroff, "Les bibles de Théodulphe et la Bible wisigothique de Cava dei Tirreni", Synthronon. Art et Archéologie de la fin de l'Antiquité et du Moyen Âge, André Grabar (ed.), ed. Librairie C. Klincksieck, Paris, 1968, pp. 153-166.

14 Paolo Cherubini, "La Bibbia di Danila: un monumento trionfale per Alfonso II di Asturie", Scrittura e Civiltà, 23 (1986), pp. 75-131. Mario Rotili, La miniatura de la Badia di Cava (see Note 3), vol. 2, pp. 21-44.
} 
Oviedo ${ }^{15}$. García Leal's contribution to the complementary study of the manuscript's 2010 facsimile is, however, an inventory, folio by folio, of all decorative motifs in the manuscript. García Leal's study lacks an artistic contextualization of the decoration within the wider panorama of the pre-Romanesque arts of Asturias, not to mention the symbolism of the Cross and the aniconic character of the entire programme, particular relevant in the wider Iberian and European contexts of the early ninth century.

\section{Sign and Symbol: Some Motifs as Textual Markers}

The different Cross motifs are the most outstanding visual components of the Danila Bible's cycle, but they are not the manuscript's only visual content - Canon tables and animal and geometric symbols in the form of initials, are among other sorts of decoration used by the artists. These motifs acted as textual markers, becoming references during the reading of the different passages ${ }^{16}$. In the case of the Canon tables in particular, these structures also helped the reader to understand the order of the Gospels and the parallels in terms of both content and interpretation between the different evangelical accounts ${ }^{17}$. The decoration of these Canon tables, by way of rather simple portico-like settings composed of arches and columns, was a widespread element in early medieval manuscript illumination across Europe and the eastern Mediterranean. Some of the earliest examples are from early Byzantine Syriac-speaking areas, like the Rabbula Gospels (Florence, Biblioteca Mediceo-Laurenziana, cod. Plut. I 56, early sixth century). This is a tradition that was also continued and enhanced during the Middle Byzantine world ${ }^{18}$. However, it is in the Carolingian Empire where perhaps the richest and most impressive examples of decorated Canon tables in Latin manuscripts are found, likely stemming from the common heritage that Roman wall painting represented ${ }^{19}$. The Soissons Gospels (Paris, Bibliothèque nationale de France, lat. 8850, early ninth century), for instance,

\footnotetext{
15 Garcia Leal, "La ornamentación de la Biblia de Cava", pp. 115-202.

16 Frederic G. KenYon, "Book divisions in Greek and Latin literature", William Warner Bishop: A tribute, Harry Miller Lydenberg, Andrew Keogh (eds.), ed. Yale University Press, New Haven, 1941, pp. 63-75. Diana Albino, "La divisione in capitoli nelle opera degli Antichi”, Annali della Facoltà di Lettere e Filosofia. Università di Napoli, 10 (1962-63), pp. 219-234.

17 Carl Nordenfalk, "The Eusebian Canon-Tables: some textual problems", The Journal of Theological Studies, 35 (1984), pp. 96-104. Eric Palazzo, “L'illustration dans l'évangéliaire au Haut Moyen Âge”, La Maison Dieu, 176 (1989), pp. 67-80. Adrian KELLER, "Le système espagnol de réglure dans les manuscrits visigothiques", Actas del $8^{\circ}$ coloquio del Comité Internacional de Paleografía Latina (Madrid-Toledo, 29 de Septiembre - 1 de Octubre, 1987), Madrid, 1990, pp. 107-114. Josefa SAnz Fuentes, Elena Rodriguez Diaz, "Un nuevo fragmento de biblia visigoda a tres columnas. Estudio paleográfico y codicológico", in: Actas del VIII coloquio del Comité Internacional de Paleografía Latina (Madrid-Toledo, 29 septiembre-1 de octubre, 1987), Madrid, 1990, pp. 211-220.

18 Carl Nordenfalk, Die Spätantiken Kanontafeln, Kunstgeschichtliche Studien über die eusebianische Evangelien-Konkordanz in der vier ersten Jahrhunderten ihrer Geschichte, ed. O. Isacsons, Gothenburg, 1938, pp. 57-64.

19 Marie-Pierre Laffitte, Charlotte DenoËL, Trésors carolingiens: Livres manuscrits de Charlemagne à Charles le Chauve, ed. Bibliothèque Nationale de France, Paris, 2007, pp. 97-100. Elisabeth RosEnBAum,
} 
with its realistic fauna and complex architectural settings made of Solomonic columns and marble-like arches, are probably among the best examples of ninth-century Canon compositions.

The Canon tables of the Danila Bible are not as lavishly decorated as their Frankish counterparts, but they represent nonetheless remarkable examples of this type of Bible illustration, and the first such use in medieval Spain [Image 1] ${ }^{20}$. The profusion of the palette and, especially, the richness of the marble seams that the columns evoked, are telling about a scriptorium with apparent means, yet perhaps in its beginnings as an active manuscript workshop. That is particularly true in the second folio, both in the recto and the verso, where a second group of Canon tables was depicted on the parchment showing a remarkable realism in the representation of the columns in particular. These support elements are made of blue and red marble tiles, as well as geometric patterns that perhaps tried to recall some sort of glazed ceramic decorations.

Another relevant component of these Canon tables is the representation of horseshoe arches. This is a well-known architectural invention of Visigothic Spain, later used (and re-used) by both the Cordoba Umayyads in the south and the Mozarabs along the Duero Valley further north ${ }^{21}$. Their use rapidly spread to the manuscript illumination of these northern territories of the peninsula, as depicted in some of the earliest Mozarabic copies of the Commentary on the Apocalypse by Beatus, such as that of Távara (Madrid, Archivo Histórico Nacional, cod. 1097B ${ }^{22}$. The Canon tables of the Danila Bible can be therefore considered an indication of this shared heritage that ultimately stemmed from earlier Visigothic art and architecture ${ }^{23}$.

This idea of common visual inheritance and persistent aesthetic trend also appears in a series of small motifs depicted throughout the pagination of the Danila Bible. This figuration is overall simple, yet, of rich colours and sometimes made of intricate patterns that immediately catched the reader's eye. These motifs are normally located between different Biblical books or texts and their function was merely visual - they were a tool for the reader to clearly mark the end of the precedent text and the beginning of the new one, dividing not only pages but also reading times in both the liturgy and the private study of the manuscript's contents ${ }^{24}$. Among many of these examples, the pair of opposite birds eagles on folio $24 \mathrm{r}$ is particularly remarkable. The eagles assumed a "U"-shape and were situated below the decorated frame that marked the beginning of

\footnotetext{
"The Vine colums of Old St Peter's in Carolingian Canon Tables", Journal of the Warburg and Courtauld Institutes, 18 (1955), pp. 1-15.

20 Garcia Leal, "La ornamentación de la Biblia de Cava", p. 157.

21 María Cruz Villalón, Enrique Cerrillo Martin de Cáceres, "La iconografía arquitectónica desde la Antigüedad a la época visigoda: ábsides, nichos, veneras y arcos", Anas, 1 (1988), pp. 187-204 (pp. 194-196).

22 Charles R. Dodwell, The pictorial arts of the West, 800-1200, ed. Yale University Press, New Haven, 1993, pp. 246-247.

23 Carlos Cid Priego, “¿Existió miniatura prerrománica asturiana?”, Liño, 1 (1980), pp. 107-142 (pp. 115-120).

24 Garcia Leal, "La ornamentación de la Biblia de Cava", pp. 158-160.
} 
the Book of Leviticus [Image 2]. Their appearance recalls similar earlier Visigothic jewellery, especially brooches and earrings, also in relation to contemporary production in Merovingian Gaul ${ }^{25}$. Visigothic brooches in particular, such as the seventh-century Fíbula de Alovera, were often conceived as a pair of opposite birds ${ }^{26}$. In terms of meaning, however, the creation of this rich initial in particular cannot be entirely explained. Often for propagandistic reasons, the eagle was certainly associated with the Imperial rank in the visual culture of the post-Roman Early Middle Ages. However, in the Danila Bible this motif also inaugurated the Leviticus Book, famous for the Jewish dietary laws and the explicit prohibition of impure meats, among which that of the eagle (Leviticus 11:13).

The same can be said about another particularly well-rendered motif - that of a fish that, as part of an "E" initial, marks the beginning on folio 47r of the Book of Joshua after an introduction by St Jerome [Image 3]. For different reasons, the fish had been widely associated with the figure of Christ in Early Christian $\operatorname{art}^{27}$. Joshua was also later identified and compared as a Biblical type of Christ, and a myriad of references to his book (anointment, leadership, the walls of Jericho, etc) abound in New Testament narratives $^{28}$. On the other hand, the Book of Joshua also described to its audiences stories of endless campaigns and the determined will of a people and their leader to conquer the Promised Land. These narrations probably resonated strongly among the early ninth-century northern Spanish courts and the Church, besieged by the yet almighty Umayyad armies of al-Andalus and a pervading sense of divine mission and inpending religious war. It is therefore extremely difficult to entirely seek for interpretations behind these beautifully elaborated symbols, especially in relation to the Biblical text that they illustrated or the historical context that witnessed their appearance.

\section{Cross and Text in the Danila Bible}

This circumstance changes in the analysis of the often large motifs in the shape of a Cross that also decorate the Danila Bible. The Cross was not only an aniconic symbol of the Christian faith. As a sign, the Cross possessed its own meanings, particularly to ninth-century audiences. This section will analyze a number cross motifs of different forms and functions that were inserted at different stages of the bible's pagination. Other,

\footnotetext{
25 Gisela Ripoll Lopez, "Visigothic jewellery of the sixth and seventh centuries", From Attila to Charlemagne. Arts of the Early Medieval period in the Metropolitan Museum of Art, Katherine Reynolds Brown, Dafydd Kidd, Charles Little (eds.), ed. Yale University Press, New Haven-New York, 2000, pp. 188-203. Barry Ager, "Byzantine influences on Visigothic jewellery", Intelligible Beauty: Recent research on Byzantine jewellery, Chris Entwistle, Noël Adams (eds.), ed. British Museum, London, 2010, pp. $72-82$. Jacques Guilmain, "Zoomorphic decoration and the problem of the sources of Mozarabic illumination", Speculum, 35, (1960), pp. 17-38.

26 Reynolds Brown, "Fibulae", The art of Medieval Spain, n. 23, p. 65.

27 Robin M. JEnsEn, Understanding Early Christian art, ed. Routledge, Abingdon, 2000, pp. 50-57.

28 Richard Ounsworth, Joshua Typology in the New Testament, ed. Mohr Siebeck, Tubingen, 2012, pp. 10-18, 55-97.
} 
minor cross-shaped motifs also appear in addition to these larger symbols. One example is the initial " $\mathrm{V}$ " illustration of folio $57 \mathrm{r}$ [Image 4]. The decoration is so small that it is today impossible to develop a wider narrative of aesthetic comparison or cultural analysis. The same is not true of a number cross-shaped motifs and calligrams that will be now discussed here.

Some of these decorations were conceptualised as textual markers, such as fronstispieces in the form of a cross displaying text inside them. Others, following perhaps a contemporary Carolingian trend, were portions of text that deliberately took the form of crosses. Finally, one particular example of these "crosses" in the Danila Bible barely presents any text whatsoever, perhaps acting as a purely decorative motif in the minds of the Spanish artifices.

The first of the crosses in the Danila Bible appears on folio 100v [Image 5]. This motif has been considered by García Leal purely a textual marker - a device to help visualising the beginning of a commentary by St. Jerome on the Book of Psalms. The most noticeable feature of this cross is naturally its distinctive form. The motif is made of two large upper and lower oblong arms and two much smaller lateral curved arms. A six-petal flower motif was also depicted right at the centre of the whole composition. This is the only textual marker in the Danila Bible with this specific form. Across the manuscript's pagination, decorated mandala-like circular compositions or rectangular frames normally host the titles of books, prayers, and commentaries. The edges of this cross were also decorated with enchained spiral motives of a pale whitish colour, slightly different from that of the manuscript's parchment.

The form of this peculiar cross motif in the Danila Bible recalls later processional crosses, such as the San Millán de la Cogolla ivory cross (La Rioja region, late tenth century), now divided between Paris and Madrid ${ }^{29}$. In the manuscript, the spiral decoration on the edges of this cross evokes the carving techniques used by the Mozarabs in devotional crosses such as that of San Millán. In the borderlands of the Duero Valley, decorated crosses were often displayed during ordinary liturgical services at the altar area, as well as during more public activities, like indoors and outdoors processions on specific feasts. During those occasions, the liturgical services and the meaningfulness of the celebration attracted large flocks of population. Ivory crosses such as that from San Millán de la Cogolla represented probably the best of Mozarabic applied arts with a liturgical function, but much has been said about their origin. San Millán was probably

29 Dodds, The art of medieval Spain, pp. 149-150. Ernst KüHnEL, Die islamischen Elfenbeinskulpturen, VIIXIII Jahrhundert, ed. Deutscher Verlag für Kunstwissensschaft Berlin, 1971, pp. 49-50. Danielle GABORITChopin, Ivoires du Moyen Âge, ed. Office du Livre, Fribourg, 1978, p. 91. Jacques FonTAIne, L'art prérroman hispanique, vol. 2, ed. Zodiaque, Paris, 1977, pp. 371-372. Danielle PERrIER, Die spanische Kleinkunst des 11. Jahrhunderts. Zur Klarung ihren stilistichen Busammenhänge im Hinblick auf die Frage ihrer Beziehungen zur Monumentalskulptur, ed. Aachener Kunsblätter, Aachen, 1984, pp. 97-98. Gonzalo MenENDEZ PIDAL, "Mozárabes y asturianos en la cultura de la Alta Edad Media, en relación especial con la historia de los conocimientos geográficos", Boletín de la Real Academia de la Historia, 134 (1954), pp. 137-178. 
the most developed ivory carving workshop in northern Spain around the year 1000, but the stylistic relationship with ealier and contemporary Islamic Andalusian craftswork is evident. Glaire Anderson argued that there was in intimate connection between San Millán in particular and the Navarran court at Pamplona, with active centres of ivory production further south, in Islamic-controlled lareas ${ }^{30}$.

The chronology of the materials preserved today is evidently later than that of the Danila Bible. These ivory crosses date mostly from the late tenth- and the first half of the eleventh centuries. However, the idea of an external interaction in Asturias with earlier, non-preserved examples of this type of crosses from the Duero Valley and beyond, is sufficiently reasonable. Historian Juan Uría Riu hypothesised about such a relationship in times of Alfonso II, tainted in modern historiography by established pre-conceptions about the period fuelled by twentieth-century Spanish nationalism ${ }^{31}$. In this case, workshops in Toledo or Córdoba, cities at the centre then of the splendour of the Andalusian emirate, perhaps began providing occasionally precious objects for Christian courts and monastic communities further north. The actual exchange was probably never direct. Mixed populations of Mozarabs, spread throughout the Duero valley, a true frontier land between al-Andalus and the Kingdom of Asturias, could have played a role of reception and exchange of goods from the south, to be dispatched then further north to the most important Christian settlements, Oviedo and Santiago. The Asturian capital had been experiencing since the late eighth century a population growth, centralisation, and constant initiatives of royal patronage resulting in the creation of important palatine and ecclesiastical foundations.

The aspect of these potential earlier Mozarabic crosses is unknown but the San Millán cross perhaps represented a certain continuity of an earlier tradition of ivory carving associated with Islamic crafts from the south of the Peninsula. It is widely known today that ivory workshops in the Andalusi capital were then at the peak of their importance while the Danila Bible was created around the year 800 . The composition of these workshops, especially those that also produced Christian objects for liturgical use, is highly arguable, but specialists do not exclude today Christian Mozarabs working together with fellow Muslim craftsmen ${ }^{32}$. The scarcity of ivory in northern Spain is also telling about the role that workshops and subsequent trade with al-Andalus could have played in the creation of some of the finest examples of later sculpture in Christian Spain. Crosses made of ivory may have been seen around the year 800 as particularly exotic among Asturian high-ranking circles, both civil and ecclesiastical.

30 Glaire Anderson, "Sign of the Cross: contexts for the ivory Cross of San Millán de la Cogolla", Journal of Medieval Iberian Studies, 6 (2014), pp. 15-41(pp. 33-36).

31 Juan URIA Riu, "Notas para el estudio del Mozarabismo en Asturias", Revista de la Universidad de Oviedo, 8 (1947), pp. 5-23.

32 Anthony Cutler, "Ivory working in Umayyad Cordoba: techniques and implications", The ivories of Muslim Spain, Kjeld von Folsach and Joachim Meyer (eds.), ed. The David Collection, Copenhagen, 2005, pp. 36-47. Julie Harris, "Muslim ivories in Christian hands: the Leire casket in context", Art History, 18/2 (1995), pp. 213-221. Emilio CABRERA, "Musulmanes y cristianos en al-Andalus: problemas de convivencia", Antigüedad Cristiana, 28 (2011), pp. 119-133. 
The second cross displayed inside the Danila Bible appears on folio 143r [Image 6] ${ }^{33}$. Due to its iconic form, this type of cross is sometimes referred as "Gothic" cross. This second motif, depicted full-page, is relatively similar to the previous cross, although all four arms have now the same dimensions and, hence, parallels with Mozarabic processional crosses, of a more elongated form, are difficult to establish. However, it is evident that its creation was paramount for the artifices of the manuscript, since it was depicted full-page. This motif was positioned at the centre of a frame made of a simple but continuous vegetal pattern and surrounded by four flower-like motives on the angles, as well as four knot-like circles attached to the frame. This highly symmetrical composition was carefully designed beforehand, the cross representing the centre of it. Furthermore, an inscription - crux - on the top of the upper arm was also left by the scribes, not to merely identify the object, but to remark its symbolic importance to viewers from a certain distance ${ }^{34}$.

The reason for which this cross was depicted on this specific folio is unknown. The decision to create a full-page symbol of the Cross, accompanied by an inscription, perhaps responded to a pure pragmatic motivation. Located roughly in the middle of the manuscript's 303 folios, the cross was framed and occupied most of the folio's recto, being easily perceived when the manuscript was open at this stage. After its creation, the monumental Danila Bible, an ambitious enterprise of scribal work probably sponsored by a monarch, may have been displayed for long periods of time on some sort of altar, perhaps during Mass or conciliar proceedings at Oviedo Cathedral, or at another, more private setting inside the attached royal complex in the case of the Asturian capital. If the manuscript stood permanently open during certain periods of time, this full-page motif of folio 143 was thus probably shown to the audience ${ }^{35}$.

Moreover, in the minds of ninth-century learned Asturian circles, wary of showing and perceiving any sort of figuration of Christological nature, this complex geometric decoration perhaps evoked indirectly Christ himself. Seen today, the arrangement of this cross and the four flower-like additional motifs also recalls contemporary Bible illustrations in Carolingian Francia that had a Christ, normally as a Maiestas Domini, at the centre of symmetrical frontispiece compositions featuring the Four Evangelists and/ or the Tetramorph on the corners ${ }^{36}$. An example of such an arrangement is provided by the First Vivien Bible from Tours, c. 845 (Paris, Bibliothèque nationale de France, Lat. 1 , fol. $329 \mathrm{v}$ ). It is finally also worth noting that the same types of cross and geometric composition around it are also found on the manuscript's leather front cover at La Cava

\footnotetext{
33 Garcia Leal, "La ornamentación de la Biblia de Cava", pp. 161-162.

34 Celia Chazelle, The Crucified God in the Carolingian era, ed. Cambridge University Press, Cambridge, 2001, pp. 118-131. André WiLmart, “Prières médiévales pour l'adoration de la Croix”, Ephemerides liturgicae, 46 (1932), pp. 22-65.

35 Chazelle, The Crucified God, pp. 152-158.

36 Beatrice Kitzinger, "Representing the Gospels beyond the Carolingian center", Imago libri. Représentantions carolingiennes du livre, Charlotte Denoël, Anne-Orange Poilpré, Sumi Shimahara (eds.), ed. Brepols, Turnhout, 2018, pp. 151-161.
} 
Abbey ${ }^{37}$. However, the chronology of this binding and the leather cover could be much later, very likely once the manuscript found its way into Italy in the High Middle Ages. In addition to these two motifs of large dimensions, a number of calligrams in the Danila Bible also took the shape of a $\mathrm{Cross}^{38}$. Some of these calligrams are headings that were written in the rubrication red of the scriptorium, adopting the form of a cross displayed in between four portions of text, such as folio 194r [Image 7]. Other calligrams, such as that on folio 224v [Image 8], granted more importance to the cross-shaped portion of the text, normally a short prologue to a book by a renowned Church Father or a particularly important epistle.

Several folios of the Danila Bible were also dyed in purple (three) and in blue (four) [Image 9]. These folios, displaying both Canon tables and calligrams, are perhaps the most complex displays of means and scribal innovation of the scriptorium. The purple parchments of the Danila Bible, probably dyed with Murex that arrived from the Mediterranean, find counterparts in some of the most luxurious examples of Carolingian manuscript illumination around the year $800^{39}$. Well-known manuscripts such as the Godescalc Gospels (Paris, Bibliothèque nationale de France, lat. 1203) or the Vienna Coronation Gospels (Vienna, Hofburg Palace, Schatzkammer, inv. XIII 18) were the result of the direct patronage of Emperor Charlemagne and his entourage at Aachen. Most of the text in the former was framed and appeared over a purple background. In the case of the Vienna Gospels, commissioned for Charlemagne's coronation in 800, many folios were entirely dyed in purple, including Canon tables. The Danila Bible seems to have echoed this popular development of the scriptoria attached to the Carolingian court, perhaps stemming from much earlier Late Antique and early Byzantine conventions.

In this comparative context, the four pages of the Danila Bible dyed in blue were, however, far more rare. Folio 220r displays the Letter of St Jerome to Pope Damasus, an epistolary text in which the Church Father urged the pontiff to commission a Latin version of the Bible. Portions of the text took the form of a cross-shaped calligram, while the entirety of the parchment surface was dyed in blue beforehand [Image 9]. The Spanish scriptorium used indigo (Indigofera tinctoria) in this process ${ }^{40}$. The Vienna Coronation Gospels occasionally display blue-dyed folios together with normal or purple-dyed ones, but this solution remains overall extremely rare in Carolingian Eu-

\footnotetext{
37 Frauke Steеnвоск, "Kreuzförmige Typen frühmittelalterlicher Prachteinbände", Das erste Jahrtausend: Kultur und Kunst im werdenden Abendland an Rhein und Ruhr, vol. 1, Victor Elbern (ed.), ed. Schwann, Düsseldorf, 1962, pp. 495-513.

38 Roger Hinks, Carolingian art. A study of early medieval painting and sculpture in Western Europe, ed. University of Michigan Press, Ann Arbor, 1935, pp.72-93. Mary FrankLin-Brown, Reading the world: Encyclopedic writing in the Scholastic Age, ed. Chicago University Press, Chicago-London, 2012, pp. 244-245.

39 Recent scholarship on dyes and processes appears in: Charlotte DenoëL, Patricia Roger PUYo, AnneMarie Brunet and Nathalie Poulain-Siloe, "Illuminating the Carolingian era: New discoveries as a result of scientific analyses", Heritage Science, 6:28, 2018 (https://doi.org/10.1186/s40494-018-0194-1).

40 Laura Rodríguez Peinado, "Púrpura. Materialidad y simbolismo en la Edad Media", Anales de Historia del Arte, 24 (2014), pp. 471-495 (pp. 484-486).
} 
rope. It is, however, in the wider Mediterranean world that this peculiar technique in early medieval manuscript illumination finds its closest parallels. The so-called "Blue Qur'an" is a ninth-century Islamic manuscript whose origins have been constantly debated. Recent research has pointed to Tunisia, although an Andalusian origin has also been considered ${ }^{41}$. The folios of this luxury copy of the Qur'an were extensively dyed with indigo, the text being also gilded ${ }^{42}$. Elena Rodríguez Díaz already remarked the similarities in technique between the Asturian bible and the Islamic manuscript, especially if an Andalusian provenance is indeed certain ${ }^{43}$.

These blue-dyed folios of the Danila Bible in particular are telling about a much wider artistic interaction with other regions that are not necessarily Christian. In a more recent contribution, Rodríguez Díaz has indeed highlighted the cross-cultural nature of the bible's manufacture. Regardless of a specific provenance, Rodríguez Díaz stated that the Danila Bible was produced in a scriptorium in which all these different aesthetic traditions (aniconism, Byzantine-Carolingian canon tables and purple folios, Islamic blue-dyed folios) were sufficiently known and accordingly appreciated. ${ }^{44}$ If the work of ivory pointed with special emphasis to the Umayyad emirate in the south of the peninsula, these parchment colouring techniques perhaps highlight once more an important cultural exchange with the far more advanced Andalusian civilisation that many medieval individuals and some modern historians considered instead the enemy. The arts of the Islamic south of the peninsula, as well as their techniques and aesthetics, probably exerted a powerful fascination in the northern courts and the Church. These artistic materials perhaps arrived in the Kingdom of Asturias filtered after all through Mozarabic urban and monastic centres along the Duero Valley. This process went largely undocumented and modern historiography has also done little to remediate long-established misconceptions about the nature of cross-cultural exchanges in the polarised panorama of early medieval Spain.

\section{The Manuscript in Context: Royal Patronage and Official Aniconism}

The Asturian pre-Romanesque is widely known today for the repeated use of the Cross as a symbol that took central stage in the visual arts of the young Christian kingdom and the importance of its all-pervasive royal ideology. The different crosses of the Danila Bible, whether textual markers or calligrams, can be considered in this way part

\footnotetext{
41 Jonathan Bloom, “The Blue Qu'ran revisited”, Journal of Islamic Manuscripts, 6.2-3 (2015), pp. 196218.

42 Alain George, "Calligraphy, colour, and light in the Blue Qu'ran”, Journal of Qu'ranic Studies, 11.1 (2009), pp. 75-125.

43 Elena A. Rodríguez DíAz, "La industria del libro manuscrito en Castilla: fabricantes y vendedores de pergamino (ss. XII-XV)”, Historia, Instituciones y Documentos, 28 (2001), pp. 313-351 (p. 314).

44 Elena E. Rodríguez DíAz, "Manuscritos mozárabes: una encrucijada de tradiciones", Die Mozaraber. Definitionem und Perspektiven der Forschung, Klaus Herbers and Matthias Maser (eds.), ed. Lit Verlag, Münster, 2011, pp. 75-103, at 91.
} 
of this wider visual language of aniconic character and powerful political symbolism for Asturian monarchs, such as Alfonso II. In the early years of the ninth century, this Asturian king commissioned a portable golden cross, probably to act as a reliquary the so-called Cruz de los Ángeles. Much has been said about the technical and stylistic influences that permeated the metalsmith workshop that manufactured this cross at Gauzón Castle, and potential contacts with contemporary Carolingian metalwork ${ }^{45}$. A second cross of similar functions, but with a radically different aesthetic concept, the Cruz de la Victoria (Victory Cross), was later commissioned by King Alfonso III (866910), becoming a type of ex-voto cross thay embodied the politico-religious aspirations of the Asturian, later Leonese monarchy in Iberia ${ }^{46}$.

Also contemporary to the manufacture of this latter cross in times of Alfonso III, half a century or so after the execution of the Danila Bible, are the preserved cycle of frescos of the Church of San Julián de los Prados, also referred to as Santullano and mentioned earlier ${ }^{47}$. This church, then on the outskirts of the capital, became the key monument of King Alfonso III's reign and the Asturian monarch took great care of the decoration of the building's interior. The pictorial arts of the Asturian kingdom doubtlessly find their most extraordinary and best-preserved example in the frescos of Santullano ${ }^{48}$. A majestic "Victory" type of cross was depicted at the top of the arch that marks the end of the central aisle and the beginning of the transept. This division acted as a preliminary symbolic barrier before reaching the presbyterium area and the church's altar ${ }^{49}$. This cross symbol appears framed by a golden arch made of embedded stones and decorated columns. An urban landscape, made of two simple architectural representations, is also found at the feet of the cross. This architectural background perhaps represented a symbolic image of the palace complex built by King Alfonso I, near Oviedo Cathedral, and the spaces that hosted the scriptorium that probably manufactured the Danila Bible around the year 800 . The Santullano cross therefore embodied a spirit of royal ideology initiated by Alfonso II and the Danila Bible earlier on, a visual device that represented divine protection and mandate, as well as the royal presence and symbiosis between the Asturian court and the kingdom's Church.

The display and agency of the cross as a symbol of the monarchy did not only appear in the Asturian capital. The Church of San Martín de Salas, twenty-three miles away

\footnotetext{
45 Bertrand Favarque, "La crois des Asturies: une signification escathologique?", Famille, violence et christianisation au Moyen Âge. Mélanges offerts à Michel Rouche, Martin Aurell and Thomas Deswarte (eds.), ed. Presses de l'Université de Paris-Sorbonne, Paris, 2005, pp. 309-318.

46 Carlos Cid Priego, "La joyas prerrómanicas de la Cámara Santa de la Catedral de Oviedo", Liño, 10 (1991), pp. 7-46. Helmut Schlunk, "Crosses of Oviedo. A contribution to the history of Jewellery in northern Spain in the ninth and tenth centuries", Art Bulletin, 32 (1950), pp. 91-114. César GARCIA DE CAStro VAldes, Signum salutis: cruces de orfebrería de los siglos V al XII, ed. KRK, Oviedo, 2008. Helmut Schlunk, Las cruces de Oviedo. El culto a la Vera Cruz en el reino asturiano, ed. Instituto de Estudios Asturianos, Oviedo, 1985.

47 Conant, Carolingian and Romanesque, pp. 87-93.

48 Arias Paramo, La pintura mural, pp. 21-106.

49 Arias Paramo, La pintura mural, pp. 66-88.
} 
from Oviedo and part of a monastic complex at the centre of a vast agricultural area, underwent several enlargements and reconstructions throughout the years. However, the original building is believed to have been sponsored by Alfonso II in the early ninth century, also receiving generous endowments from later monarchs such as Alfonso $\mathrm{III}^{50}$. Royal ties were overall extremely close and the monastery's direction, perhaps willing to exhibit this royal favour, carved and set up a Victory cross tile on the walls of the church in the late ninth century. The carved tile, now on display in the regional archaeological museum, represents a counterpart to the imagery in the Santullano frescos ${ }^{51}$.

If the Victory cross type became an official symbol, in different artistic media, of the Asturian monarchy of the late century, the crosses of the Danila Bible, together with the Cruz de los Ángeles, marked a wider aesthetic approach to the symbol in the early decades of the ninth century under King Alfonso II. In this period, royal patronage was a paramount, if not the exclusive driving force in the domain of artistic patronage. The Asturian Church, on the other hand, lacking any important powers and possession beyond a few lands near the capital, depended to a large extent on the king's devotional interests and personal favour ${ }^{52}$.

The role of the Asturian king may have been fundamental in the commission of the Danila Bible. The most accepted theory today is that the execution of the manuscript occurred in the early years of the ninth century, with the plausible prospect of exhibiting the bible during a ecclesiastical council that eventually took place in Oviedo in $821^{53}$. This regional Church synod intended to consolidate the role of the institution inside the Asturian territory, which still suffered from sporadic war seasons that confronted the kingdom to al-Andalus, as well as to expand its influence beyond the actual borders of the entity, towards Galicia and the Duero Valley ${ }^{54}$. The manuscript, after being made perhaps a few years before that date, would have symbolically chaired the proceedings, which took place at Oviedo Cathedral, probably placed on an altar. Regardless of this presumed purpose, the manuscript may have also been used by the local bishop or King

50 Lorenzo Arias PARAmo, "Aproximación a la realidad material del monacato asturiano en la Alta Edad Media”, Monjes y monasterios hispanos en la Alta Edad Media, José Angel García Cortázar, Ramón Teja (eds.), ed. Fundación Santa María la Real. Centro de Estudios del Románico, Aguilar de Campoo, 2006, pp. 205-228 (pp. 213-218). Ciriaco Miguel Vigil, La iglesia de San Martín de Salas, ed. Consejo Regional de Asturias, Oviedo, 1880.

51 Ciriaco Miguel Vigil, Asturias monumental, epigráfica y diplomática: datos para la historia de la provincia, ed. Imprenta del Hospicio Provincial, Oviedo, 1887, pp. 265-266. Lorenzo Arias Paramo, "Aproximación a la realidad material" (see Note 38), pp. 215-216.

52 Francisco Javier Fernandez Conde, "El papel de la monarquía en la consolidación señorial del obispo de Oviedo", Studia Historica, 25 (2007), pp. 67-87. Maria Isabel Torrente Fernandez, "Sedes regias de la monarquía asturiana", Historia social. Pensamiento historiográfico y Edad Media. Homenaje al Prof. Abilio Barbero de Aguilera, Maria Isabel Loring García (ed.), ed. Del Orto, Madrid, 1987, pp. 575-591 (pp. 582-584).

53 Barrau-Dihigo, Historia politica del reino asturiano, pp. 83-88. Gonzalo Martinez Diez, Legislación conciliar del reino Astur (718-910) y del reino de León (910-1230), ed. Universidad de León, León, 2009, pp. 21-29.

54 Victor Aguirre CANo, "La guerra entre el emirato de al-Andalus y el reino de Asturias durante el reinado de Alfonso II (791-842)”, Boletín del Real Instituto de Estudios Asturianos, 63 (2009), pp. 181-254. 
Alfonso himself, for private prayer or public readings, perhaps on special occasions ${ }^{55}$. A personal use of the Danila Bible by Alfonso II, a learned and pious monarch with a close connection with the Church and the arts, would have also matched the bibliophile fame that Alfonso gained during this life, although the fates of a potential royal library and book collection are today unknown ${ }^{56}$. The Danila Bible eventually became possession of Oviedo Cathedral, likely as a royal ex-voto, ending in the hands centuries later of Bishop Maurizio Burdino, who later became Anti-Pope Gregory VIII (d. 1137). ${ }^{57}$ This Italian churchman became Bishop and later Archbishop of the Portuguese cities of Coimbra and Braga, respectively. He stayed in Oviedo for a number of years before returning to South Italy, carrying the manuscript with him to La Cava Abbey.

The decoration of the monumental Danila Bible, whose commission was very likely linked to the Asturian monarch himself, presents noticeable similarities to the monarchy-sponsored visual arts of the period ${ }^{58}$. The study of the few remains of Asturian pre-Romanesque arts reveals today a profound concern on behalf of patrons and artists about figurative representations of religious nature. Asturian art around the year 800 was almost exclusively aniconic. The only known exceptions today are a pair of carved pieces from the Church of San Miguel de Liño and the poorly preserved remains of a wall painting from Santo Adriano de Tuñón, both outside the capital ${ }^{59}$. The carved stones at Lillo were solid celosías (latticework) for the building's windows, their rectangular arrangement recalling carved ivory panels ${ }^{60}$. On the other hand, the recent reconstruction of the fresco at Tuñon is preliminary but the simplicity of its design is telling about a ninth-century local craftsmanship not used to depict the human body in any manner. Little evidence survives in the region from previous historical phases in order to discuss persistent local traditions. In Roman times, the region of Asturias was a somewhat peripherical area, besides the port of Gigia

\footnotetext{
55 Isidro Bango ToRviso, "Los reyes y el arte durante la Alta Edad Media: Leovigildo, Alfonso II y el arte oficial", Lecturas en Historia del arte (Ephialte), 4 (1992), pp. 17-32. Maria Isabel Torrente FernandeZ, "La corte de Oviedo", Orígenes, arte y cultura en Asturias: siglos VII-XV, María Cruz Morales Saro (ed.), ed. Lunwerg, Madrid, 1993, pp. 115-119. Francisco Javier Fernandez Conde, "La religiosidad medieval y las donaciones a la Iglesia", Las donaciones piadosas en el mundo medieval, Alfonso García Leal, ed. Universidad de Oviedo, Oviedo, 2012, pp. 9-58. Luis VAzQuez de PARGA, "La Biblia en el reino Asturleonés", La Bibbia nell'alto medioevo, Ezio Franceschini (ed.), ed. CISAM, Spoleto, 1963, pp. 257-280.

56 Isidro BANGo ToRviso, "Alfonso II y Santullano", Actas de las II Jornadas sobre el arte prerrománico y románico en el norte de España. Villaviciosa, 1985, ed. Cubera, Villaviciosa, 1988, pp. 207-237.

57 Peter Linenan, The Spanish Church and the Papacy in the Thirteenth Century, ed. Cambridge University Press, Cambridge, 1971, pp. 1-5.

58 Francisco Javier Fernandez Conde, "Cristianización y simbología del poder en la época de la monarquía asturiana”, La época de la monarquía asturiana, María Cruz Morales Saro (ed.), ed. Real Instituto de Estudios Asturianos, Oviedo, 2002, pp. 263-294.

59 Francisco Javier Fernandez Conde, María Antonia Pedregal Montes, "Santo Adriano de Tuñón: historia de un territorio en los siglos de transición", Asturiensia Medievalia, 8, (1995-1996), pp. 79-110. Sabine NOACK-HALlEY, "Tradición e innovación en la decoración plástica de los edificios reales asturianos", Papers of the "III Congreso de Arqueología Medieval Española", Oviedo, March 27 - April 1, 1989, Oviedo, 1992, pp. 174-184.

60 Lorenzo Arias Paramo, "Procedencia original de las jambas de San Miguel de Liño. Reutilización de decoración escultórica de Santa María del Naranco", Territorio, sociedad y poder, 5 (2010), pp. 5-22.
} 
(probably the modern city of Gijón or a nearby settlement) and a few villa settlements and mining outposts. Figurative mosaics have been found, but only one example of fresco painting survives. Archaeologists have recently recomposed the wall paintings of the Chao San Martín villa, now preserved in the regional archaeological museum in Oviedo ${ }^{61}$. The extant traces of painting recreated rather simple geometric compositions in vivid colours, but no figurative content is believed to have been reproduced.

For the Asturian aniconism of the early ninth century more influential and chronologically closer precedents existed - the arts of the Visigothic kingdom ${ }^{62}$. Before the settlement of the Visigoths (who were originally Arians that converted to Catholicism and, therefore, also mistrustful of religious imagery in the arts), the Iberian Peninsula in Late Antiquity, also experienced debates surrounding the nature of Christian images ${ }^{63}$. The debates and subsequent conclusions of the Elvira Synod (a town near present-day Granada) in the early fourth century shaped the approaches of the later Hispanic Church and monarchies to figurative decorations in buildings and religious art in general. The Synod's canon thirty-six explicitly forbade the use of images in churches ${ }^{64}$. However, on the ground, the evidence supporting the reception and application of this measure is meagre. The Iberian Peninsula lacks extensive early Christian and early medieval decorative programmes such as those of Ravenna or Rome. The first artistic examples of medieval visual arts in the Iberian territory are those of churches built in the late Visigothic period. Still-standing buildings such as San Pedro de la Nave or San Juan de Baños date mostly from the second half of the seventh century ${ }^{65}$. This surviving decoration is exclusively boor sculpture carved in columns or other parts of the interior of churches. Figurative and human characters forms appear often, such as in case of the celebrated capital from San Pedro de la Nave that shows the Sacrifice of Isaac. The official avoidance of images of the Old Hispanic Church was seemingly relaxed in this period. On the other hand, the impact of the Elvira's canon thirty-six on other artistic media, such as manuscripts, is unclear ${ }^{66}$.

\footnotetext{
${ }_{61}$ Luis Ramón Menendez Bueyes, Reflexiones criticas sobre el origen del Reino de Asturias, ed. Universidad de Salamanca, Salamanca, 2001, pp. 165-167. Jesús Pura Higueras, "Tratamientos de conservación de pinturas murales altomedievales", La intervención en la arquitectura prerrománica asturiana, Jorge Hevia Blanco (ed.), ed. Universidad de Oviedo, Gijón, 1997, pp. 263-272.

62 Isidro BAngo Torviso, "Las imágenes en los templos medievales. Del aniconismo a la intención docente: las tres posturas tradicionales de la Iglesia”, La enseñanza en la Edad Media, José Ignacio de la Iglesia Duarte (ed.), ed. Instituto de Estudios Riojanos, Logroño, 2000, pp. 357-382.

63 David M. Gwynn, "From Iconoclasm to Aranism: the construction of Christian tradition in the Iconoclast controversy”, Greek, Roman, and Byzantine Studies, 47 (2007), pp. 225-251.

64 José Vives, Concilios visigóticos e hispano-romanos, ed. CSIC, Madrid, 1993, pp. 7-9. Carmen GarCia Rodriguez, El culto a los santos en la España visigoda, ed. CSIC, Madrid, 1996.

65 Luis Caballero Zoreda, "La iglesia de San Pedro de la Nave (Zamora): arqueología y arquitectura", Archivo Español de Arqueología, 70 (1997), pp. 221-274. Luis CABAllero Zoreda, Santiago FeiJoo MarTINEZ, "La iglesia altomedieval de San Juan Bautista en Baños de Cerrato (Palencia), Archivo Español de Arqueología, 71 (1998), pp. 181-242.

66 Helmut Schlunk, "Observaciones entorno al problema de la miniatura visigoda", Archivo Español de Arte, 71 (1945), pp. 241-265.
} 
The case of the Danila Bible in Asturias, over a century later, is radically different insofar as the manuscript represented very likely a direct initiative of royal patronage in the capital and, therefore, the artifices were much more aware of potential theological prerrogatives ${ }^{67}$. It is plausible to conceive the aniconism in the visual arts of the Asturian kingdom the inheritance to some extent of Visigothic royal patronage, particularly attentive to official positions and ecclesiastical opinion. Late eighth- and early ninth-century sculpture in Asturias is similar to late Visigothic work, being considered boor in the same degree as well. The panels from San Miguel de Lillo show the weight of a Roman tradition in the composition of the scenes and iconography, but also point to technical difficulties when it came to craftsmanship, especially regarding the human figure. However, notable exceptions, such as the stone capital from San Pedro de la Nave, show that the official views of the Synod of Elvira, which had marked the beginning of the so-called "Hispanic Aniconism" in modern Spanish historiography, also left open the question as to how influential these ancient prerrogatives were for later courts, Church, and artistic workshops in general ${ }^{68}$.

Important historical circumstances, however, separate the case of the Danila Bible and the Santullano frescos from these examples of figurative sculpture in late Visigothic Spain - the wider European and Mediterranean contexts. If the Canons of the Synod of Elvira can be perhaps considered chronologically too early to have influenced later Visigothic thought on art, the Asturian kings were politically confronted to one of the most evident examples of aniconism in the world scene, that is, the growing importance of the Islamic faith of the almighty Emirate of al-Andalus ${ }^{69}$.

After the swift Islamic conquest of Iberia that began in the year 711, Christian churchmen in the recently occupied territory began responding to the social and theological challenges posed by the faith of the newcomers concerning the nature of Christ, Old Testament prohibitions, and the subsequent suitability of figurative representations. Successive generations of Iberian churchmen inside the lands of the Emirate or in the northern borderlands, soon manifested a will to come to terms with the ruling power. A series of debates in Toledo orchestrated by the local archbishop, Elipandus (d. 805), resulted in the formulation of the Adoptionism creed, an ideary that speculated about the adoptive human nature of Christ in relation to God. This movement, which initially gained prominent supporters in the Old Hispanic Church, such as the Urgell Bishop Felix (d. 818), was quickly considered heretical in the rest of Christian Europe, including by

\footnotetext{
67 Lorenzo Arias PARAmo, "Iconografía del poder en el arte altomedieval asturiano" (siglo VIII-IX)", Le corti nell'Alto Medioevo, Settimane di Studio del Centro di Studi dell'Alto Medioevo, Spoleto, $24^{\text {th }}-29^{\text {th }}$ of April, 2014, ed. CISAM, Spoleto, 2014, pp. 940-942.

68 Rafael Barroso Cabrera, Jorge Morin de Pablos, Regia Sedes Toletana. El Toledo Visigodo a través de su escultura monumental, ed. Real Fundación de Toledo, Toledo, 2007, pp. 84-97. Lorenzo ArIAs Paramo, La pintura mural (see Note 11), pp. 66-68.

69 Alessandra CAPUTO JAFFE, "Iconoclastia y aniconismo: correspondencias entre el mundo islámico y el cristiano", Entremons, 2 (2011), pp. 1-28. Almudena ArIZA ArmAdA, "Aniconismo e iconografía monetal en al-Andalus", Actas del Primer Simposio España-Estados Unidos, Antonio Quillis (ed.), Madrid, 2001, pp. 23-33.
} 
the Church and the monarchy in Asturias ${ }^{70}$. Bishop Elipandus died probably a few years before the commission of the Danila Bible. The Asturian Church at that time perhaps felt the attacks and social pressure of Adoptionist proponents that sought to reconcile to some extent their Christian beliefs with some of the ideas of the Islamic faith of the dominant political power in the south.

The decoration of the Danila Bible, likely the single most important manuscript ever manufactured in over a century of Asturian rule and closely linked to both Church and king, perhaps echoed this development, particularly if intended for a council of northwestern bishops in 821 . The pictorial programme of the manuscript exhibited the wealth and means of both the Asturian monarchy and the Church, also offering to the viewers a myriad of cross-shaped fronstispieces, large motifs, and calligrams, in addition to animal, geometrical, and vegetal decorations. The symbolism of these imageries was perhaps explained to this audience of visiting churchmen, noblemen, diplomats, and court officials. Purple- and blue-dyed folios probably increased this public perception of luxury and power, regadless of aesthetic associations with Carolingian and Andalusi arts. Aniconism stemmed after all from Biblical prescriptions and the Islamic presence and influence on the small Christian kingdom, filtered through Mozarabic churches, perhaps catalysed a per se traditional antagonistic sentiment of Visigothic origin against images in high-ranking Asturian ecclesiastical and courtly circles. $^{71}$

Another highly-influencial factor in official artistic patronage at the Asturian court could have been the Byzantine First Iconoclasm (726-787) and, more importantly, Charlemagne's response after the Council of Frankfurt $(794)^{72}$. This gathering in the Rhenish city witnessed vivid exchanges about the Second Council of Nicaea (787), which officially saw the restauration of the cult of images in the Byzantine Empire and the veneration in the East of "what it is represented in images" ". Perhaps due to the absence of Frankish delegates at Nicaea, the belligerent Frankfurt gathering condemned nonetheless the cult of images seven years later, highlighting instead their didactic role in the faith, but denying their sacredness ${ }^{74}$. Moreover, the Council of Frankfurt also saw the official Latin censure of Spanish Adoptionism ${ }^{75}$. The movement

\footnotetext{
70 Joanne McWilliam, "The context of Spanish adoptionism: a review", Conversion and continuity. Indigenous Christian communities in Islamic lands eigth to eigthteen centuries, Michael Gervers, Ramzi Jibran Bikhazi (eds.), ed. Toronto University Press, Toronto, 1990, pp. 75-88. Lucas Mateo Seco, "Adopcionismo hispánico y el concilio de Frankfurt", Anales Valentinos, 20 (1994), pp. 99-120.

71 Jesús Espino Nuño, Los orígenes de la Reconquista y el reino asturiano, ed. AKAL, Madrid, 1986, pp. 12-13. Dominique Millet-Gerard, Chrétiens mozarabes et culture islamique dans l'Espagne des VIIIe-IXe siècles, ed. H. Champion, Paris, 1984, pp. 49-70.

72 Thomas F. X. Noble, Images, Iconoclasm and the Carolingians, ed. Pennsylvania State University Press, Philadelphia, 2009, pp. 158-206. Michael McCormick, "Textes, images et iconoclasme dans le cadre des relations entre Byzance et l'Occident carolingien", Papers of the conference "Testo e immagine nell'Altomedioevo", ed. CISAM, Spoleto, 1994, pp. 95-158.

73 NoBle, Images, Iconoclasm, pp. 69-84.

74 NoBle, Images, Iconoclasm, pp. 158-206.

75 Chazelle, The crucified God, pp. 52-74.
} 
worried the Frankish Church since the so-called Spanish marches along the Pyrenees witnessed a growing presence of Adoptionist proponents (for instance, Bishop Felix of Urgell in Catalonia).

The power of Aachen and the Frankish Church reached the fringes of the contested Iberian territory. The Kingdom of Asturias was the most important ally of Charlemagne in the peninsula and exchanges between the two chancelleries, as well as trade, took place, mainly through Aquitaine ${ }^{76}$. In the visual arts of the Asturian kingdom, essentially propelled by the monarchy to satisfy the Church, aniconism reigned. Although a direct influence of the Byzantine troubles looks remote, Frankish attitudes towards figurational art, as reflected in the canons of the Frankfurt Council, became perhaps known to Oviedo elites in the early years of the new century. The decoration of the Danila Bible, as the Santullano frescos decades later, shows a certain awareness of this complex situation for patrons and artists that was unlikely coincidental. Unlike Carolingian scriptoria during the same years, not a single figure or scene was depicted in the most important manuscript commissioned in this peripherical, yet upcoming Iberian Christian kingdom ${ }^{77}$.

The Danila Bible remains today an object largely unknown to art historical scholarship of the Middle Ages. Yet, this preliminary analysis of the bible's decoration, which will hopefully benefit soon from further research and eventual digitisation, has shed light on the main features of one of the earliest extant manuscripts of medieval Spain. Based on the complexity and richness of the commission, the theory of King Alfonso II's patronage at Oviedo seems plausible. The manuscript was also commissioned in close collaboration with the local Church, becoming a monumental liturgical tool, didactic device, and eventual ex-voto clearly defined by its aniconism. The roots of this overlooked aesthetic language, which boasted nonetheless a myriad of decorative initials, complex frontispieces, and purple- and blue-dyed folios, were likely a combination of Iberia's Visigothic inheritance and perhaps an awareness of global historical circumstances concerning the suitability of figurative arts in religion.

The aniconism of the Danila Bible and, by extension, the arts of the Asturian kingdom in which it so comfortably fits, likely became thus an aesthetic ideology conceptualised in order to symbolically confront the religious arguments of the dauntless Andalusi emirate and the philo-Muslim Adoptionism in Iberia regarding images. Discussions

\footnotetext{
76 Marcellin Defourneaux, "Charlemagne et la monarchie asturienne", Mélanges d'histoire du Moyen Âge dediés à la mémoire de Louis Halphen, Robert-Henri Bautier (ed.), ed. Presses Universitaires de France, Paris, 1951, pp. 177-184. Alberto Gonzalez Garcia, "La proyección europea del reino de Asturias: Política, cultura y economía (718-910)”, El Futuro del Pasado, 5 (2014), pp. 225-298. Jacques FontAine, "Mozarabie hispanique et monde carolingien (Les échanges culturels entre la France et l'Espagne du VIIIe au Xe siècle)", Anuario de Estudios Medievales, 13 (1983), pp. 17-46.

77 Isidro BAngo ToRviso, "El arte asturiano y el Imperio Carolingio", Actas del Simposion "Arte prerrománico y románico en Asturias”, ed. Cubera, Villaviciosa, 1984, pp. 31-88. Antonio ThIERY, "La cultura e l'arte precarolingia e protomozarabica. Communicazione e immagine nel VIII secolo: nuovi problemi di metodo", Papers of the "Settimane di Studio del CISAM, XX: I problemi dell'Occidente nel secolo VIII”, ed. CISAM, Spoleto, 1973, pp. 723-781.
} 
about the Byzantine Iconoclasm and the Frankfurt Council, on the other hand, perhaps took also place at Oviedo in the early years of the ninth century. Through this lens, accidentally or not, the decoration of the Danila Bible seems, to say the least, respectful of this wider panorama. For the emerging Asturian court around the year 800, the Cross became then, just as on the walls of Hagia Irene in Constantinople or Santullano later on, not only the simplest embodiment of the faith, but also a suitable symbol to convey the sacredness of word and ritual to pious and fearful audiences. 
The decoration of the Danila Bible: Aniconism as Royal ideology in ninth-Century...

\section{Images}

IMAGE 1.

Danila Bible, Canon Tables (Cava dei Tirreni, Biblioteca della Badia, MS. 1, fol. 222v).

Photo: Prof. Lorenzo Arias Páramo.

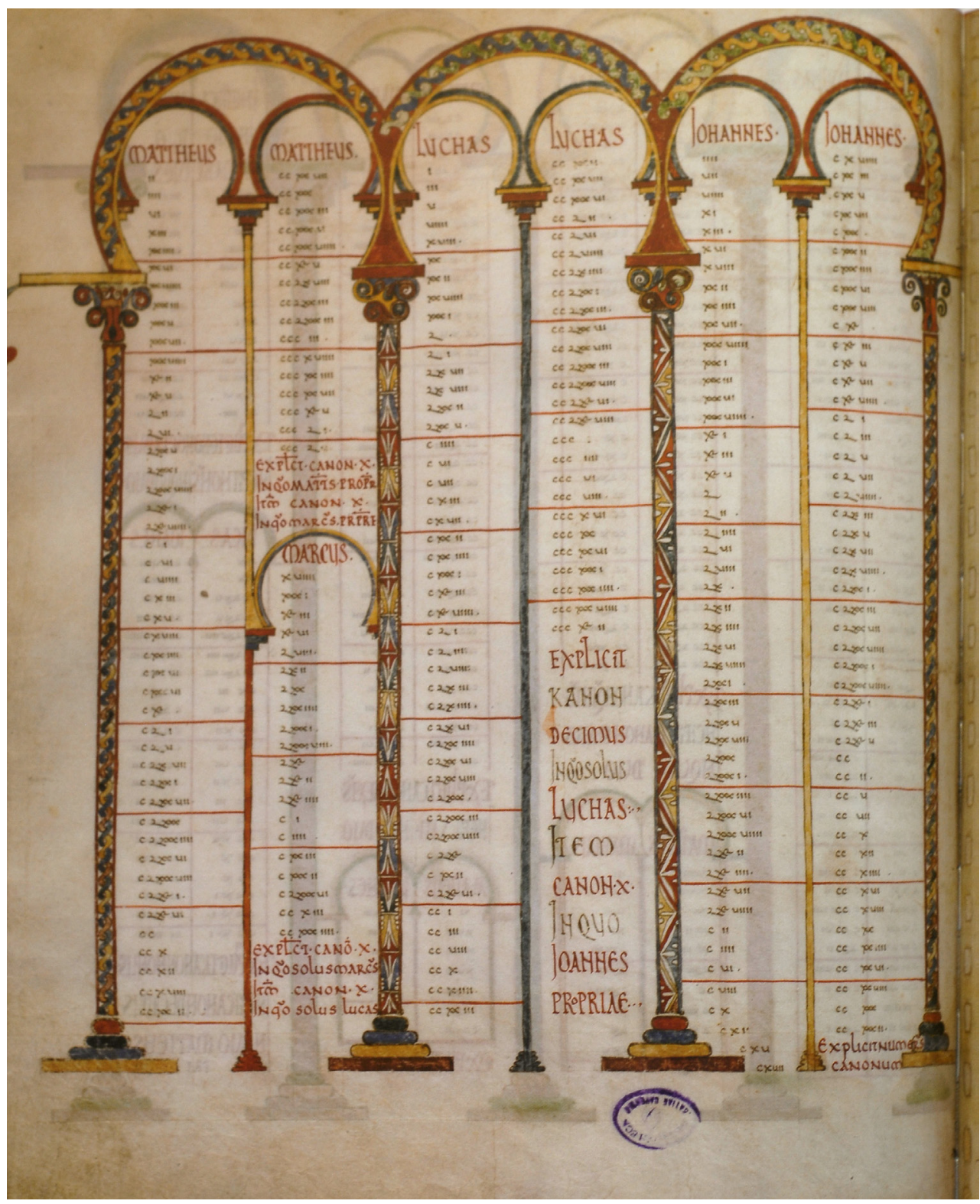


IMAGE 2.

Danila Bible, Frontispiece and initial (Cava dei Tirreni, Biblioteca della Badia, MS. 1, fol. 24r). Photo: Prof. Lorenzo Arias Páramo

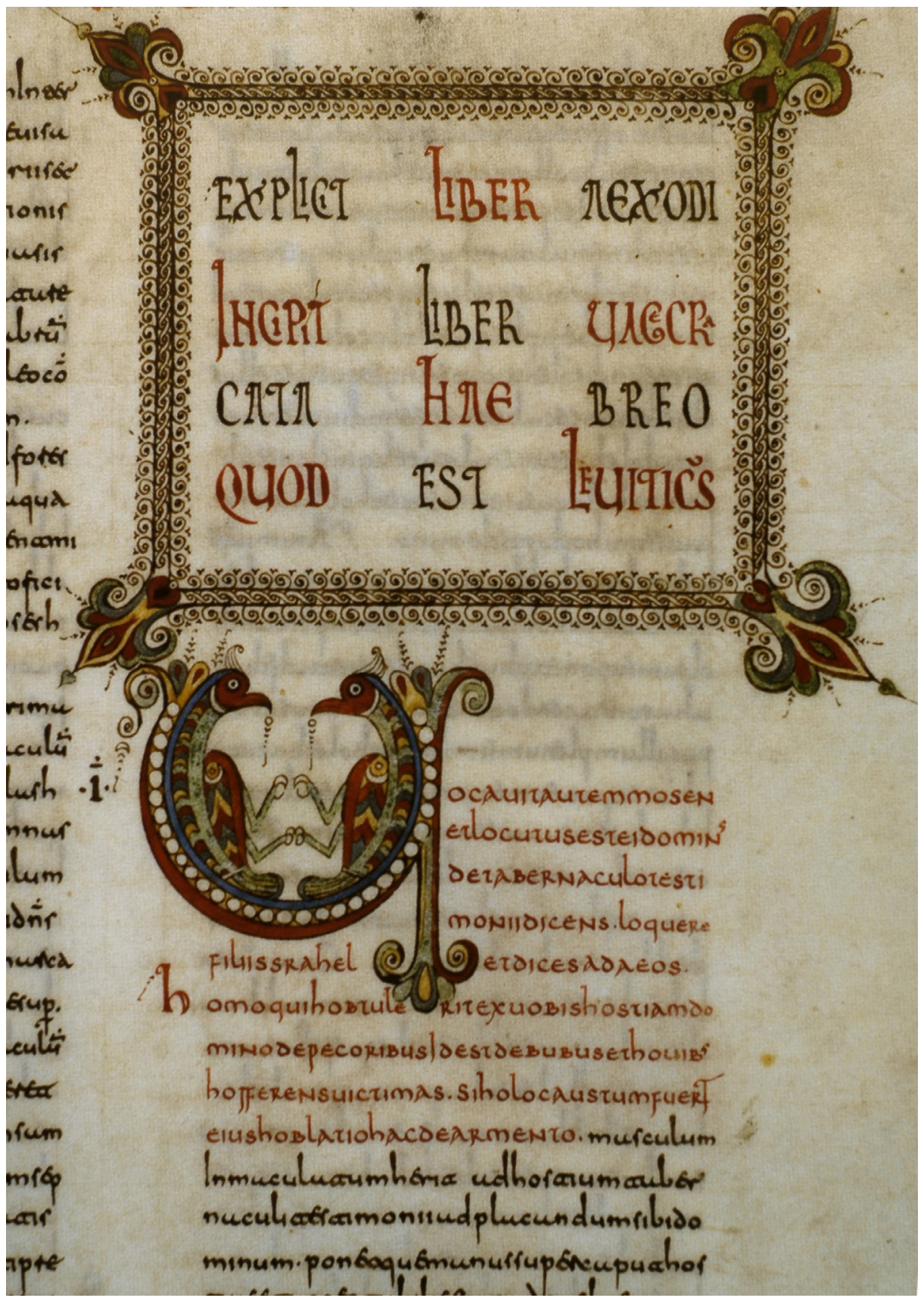


IMAGE 3.

Danila Bible, Frontispice and initial (Cava dei Tirreni, Biblioteca della Badia, MS. 1, fol. 47r). Photo: Prof. Lorenzo Arias Páramo.

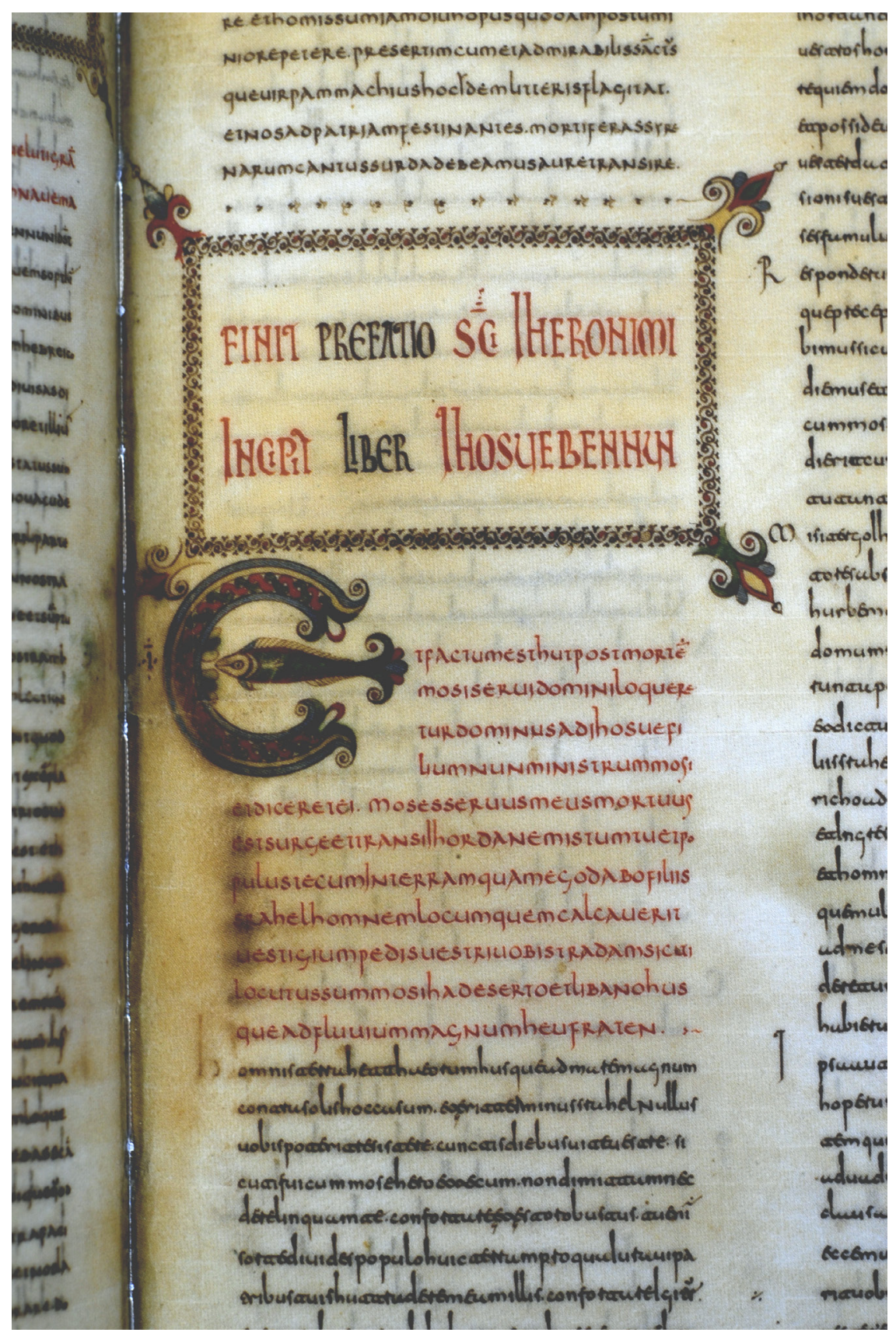


IMAGE 4.

Danila Bible, Initial and cross (Cava dei Tirreni, Biblioteca della Badia, MS. 1, fol. 57r). Photo: Prof. Lorenzo Arias Páramo.

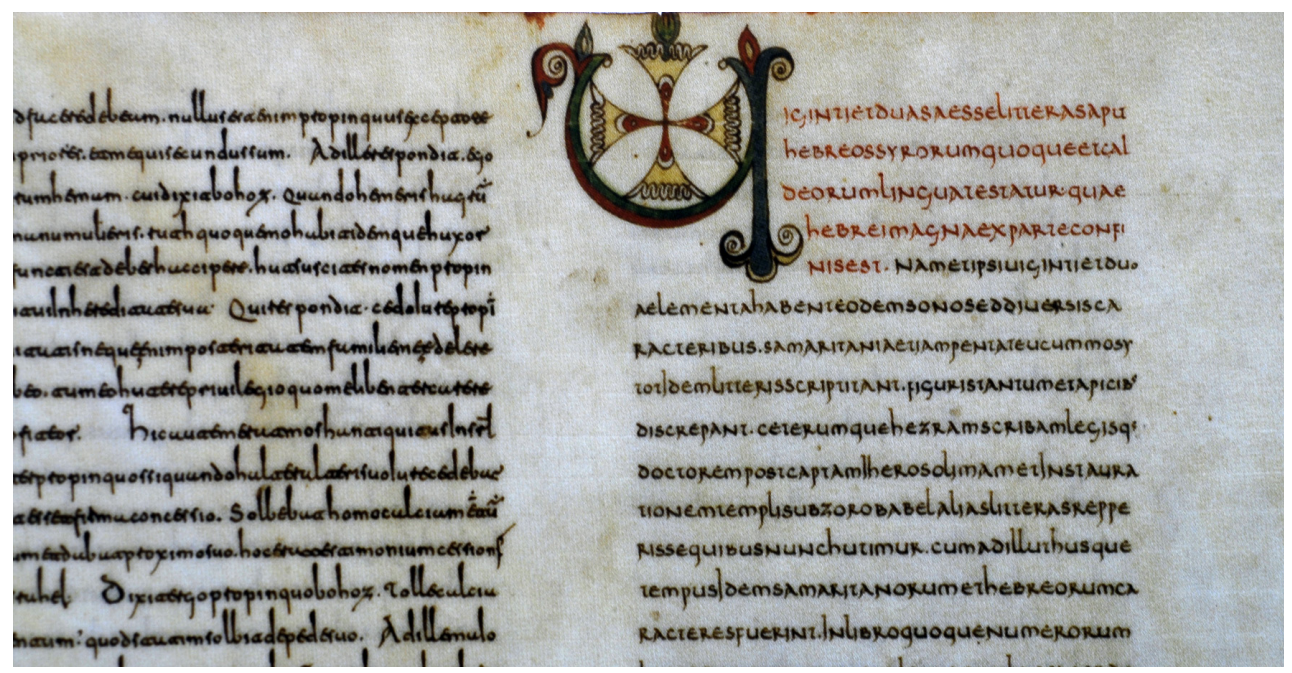


IMAGE 5 .

Danila Bible, Cross frontispiece (Cava dei Tirreni, Biblioteca della Badia, MS. 1, fol. 100v). Photo: Prof. Lorenzo Arias Páramo.

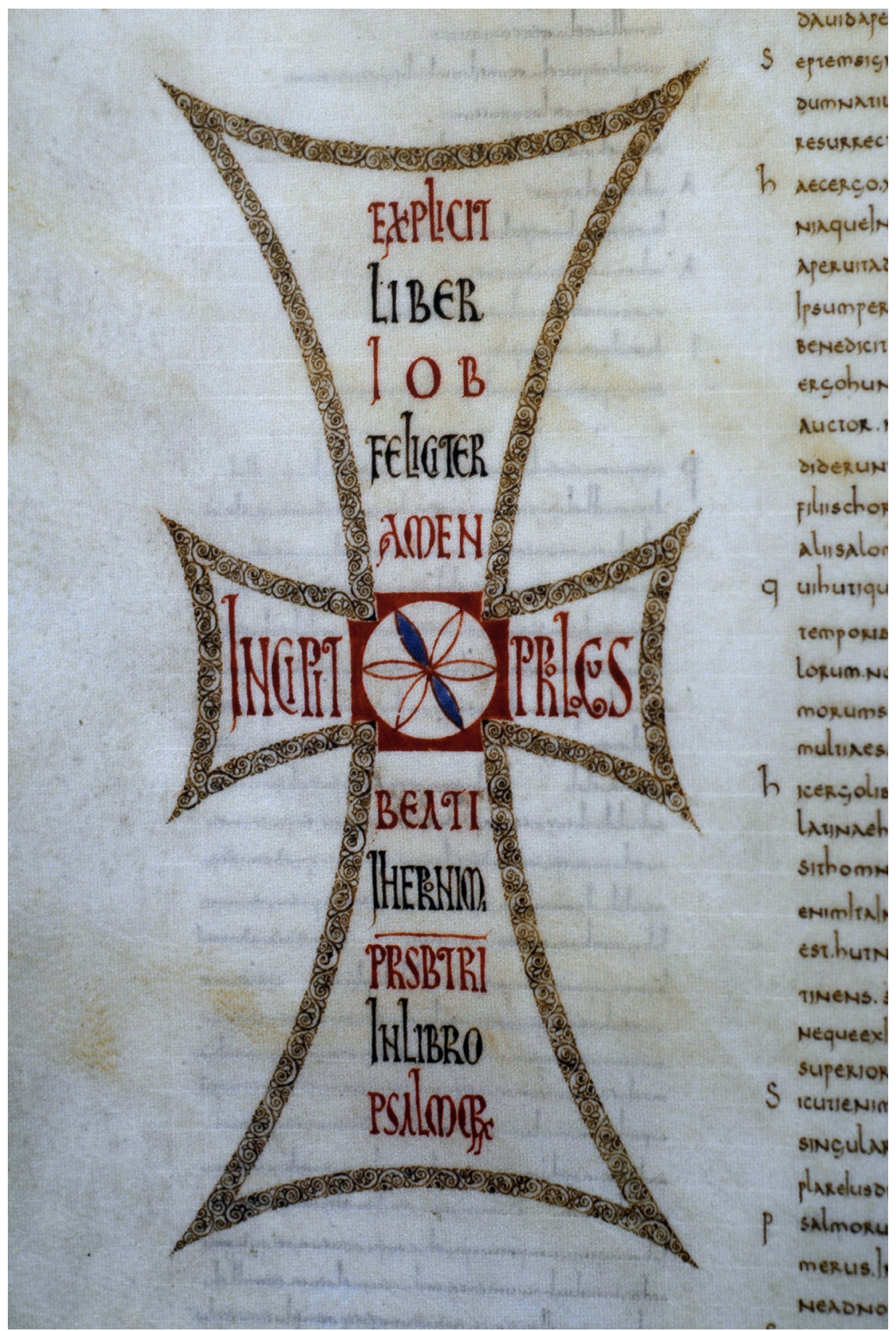


IMAGE 6.

Danila Bible, Full-page Gothic cross (Cava dei Tirreni, Biblioteca della Badia, MS. 1, fol. 143r). Photo: Prof. Lorenzo Arias Páramo.

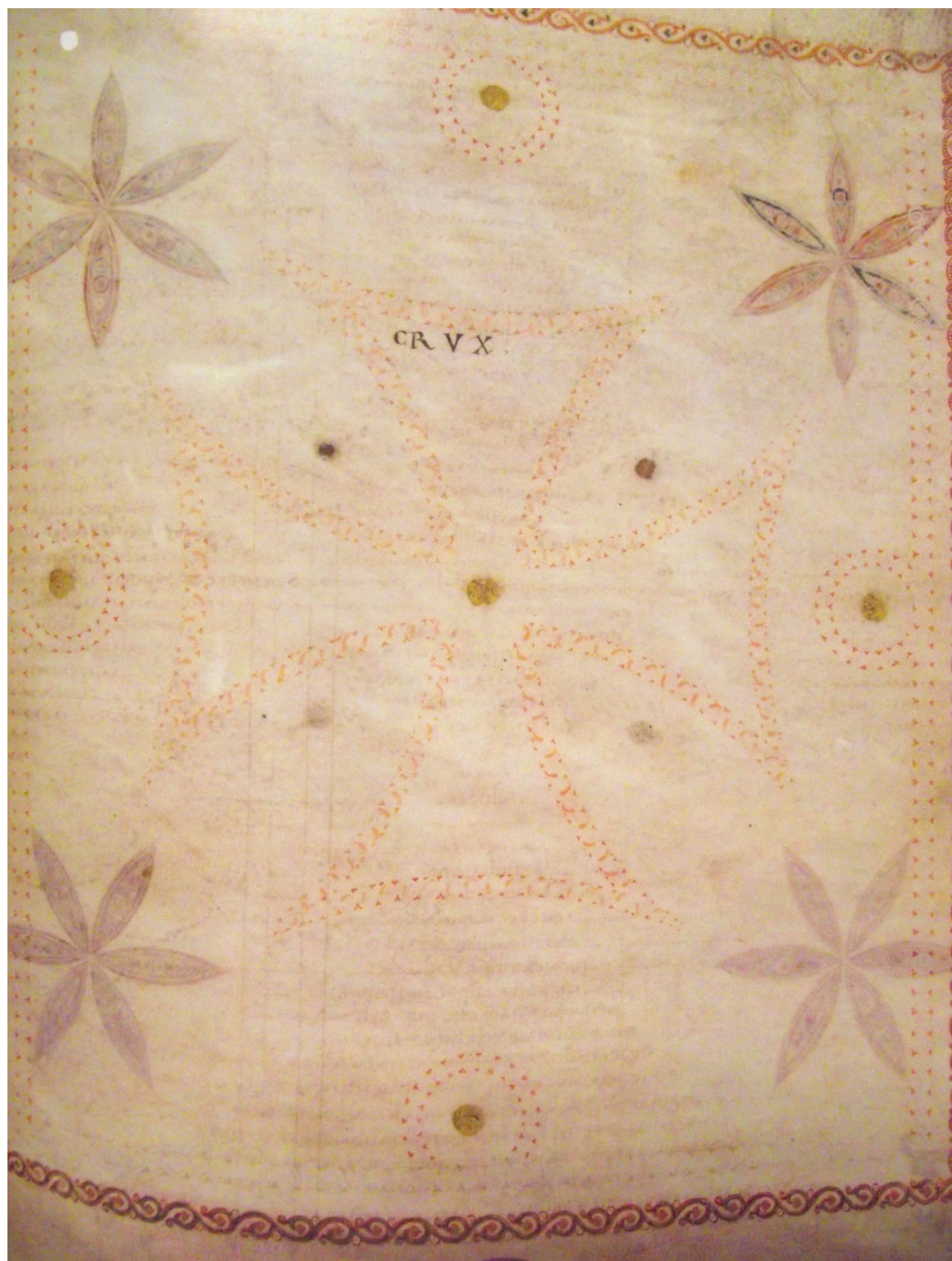


IMAGE 7.

Danila Bible, Cross-shaped calligram (Cava dei Tirreni, Biblioteca della Badia, MS. 1, fol. 194r). Photo: Prof. Lorenzo Arias Páramo.

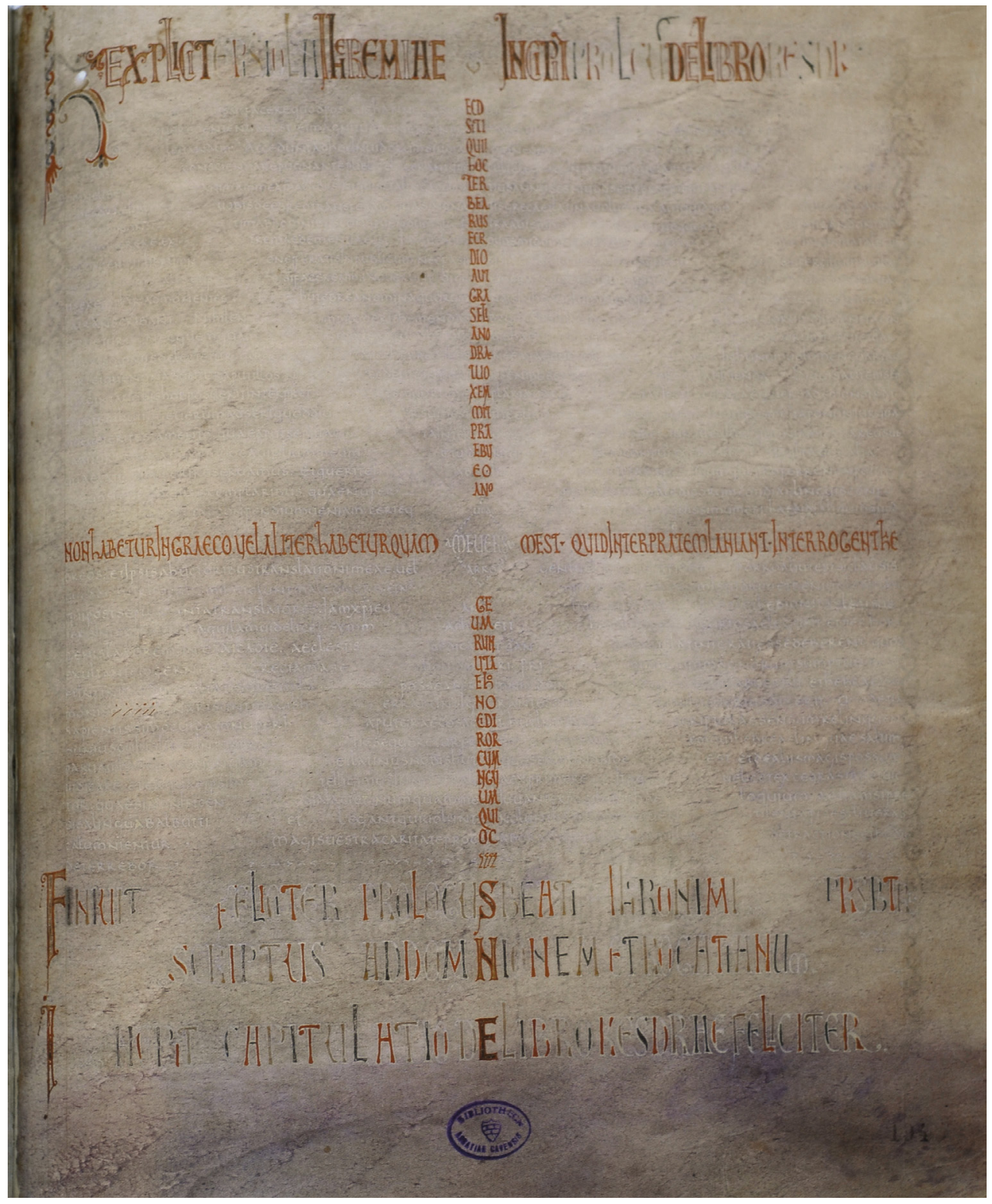


IMAGE 8.

Danila Bible, Cross-shaped calligram (Cava dei Tirreni, Biblioteca della Badia, MS. 1, fol. 224v). Photo: Prof. Lorenzo Arias Páramo.

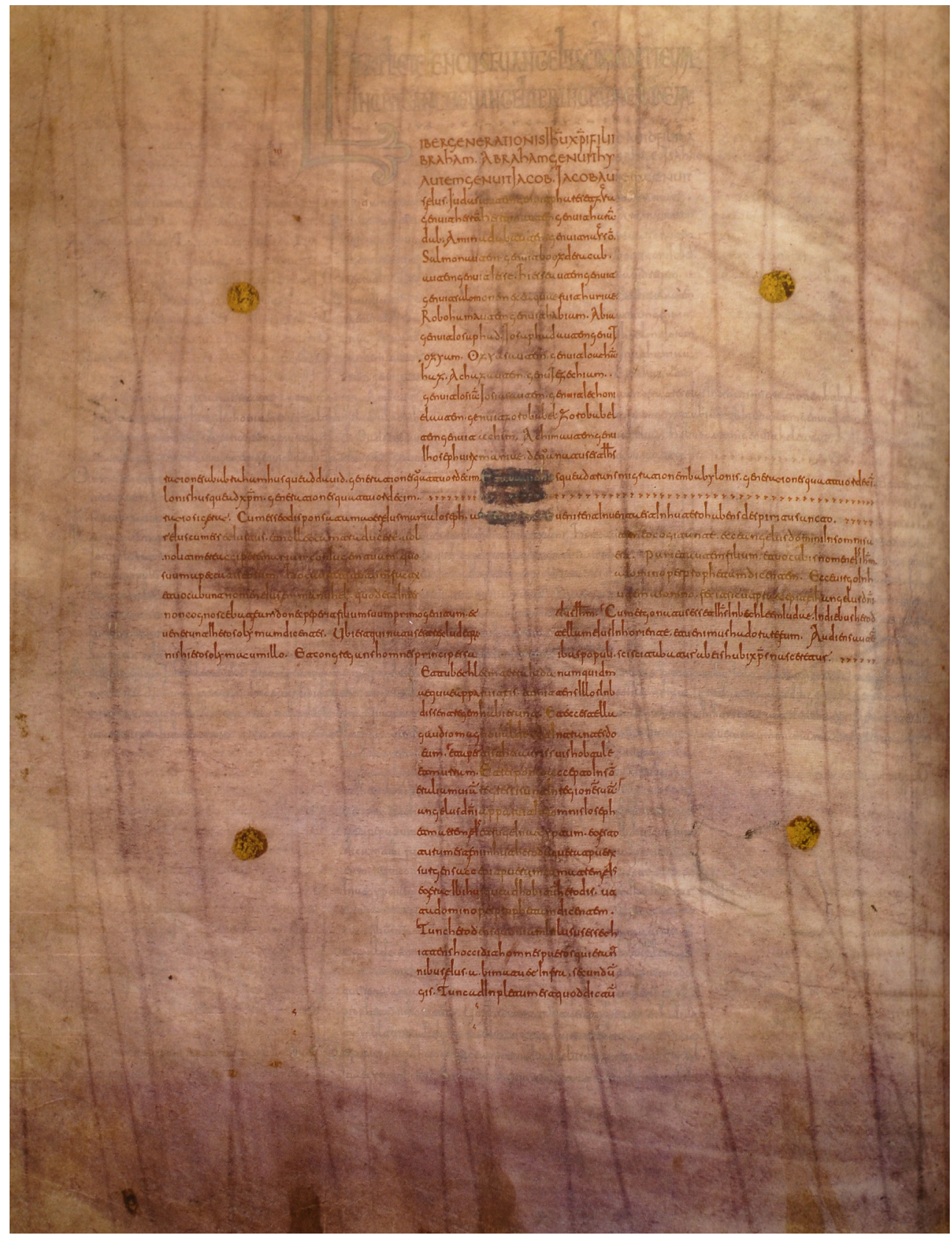


IMAGE 9.

Danila Bible, Calligram and blue-dyed folio (Cava dei Tirreni, Biblioteca della Badia, MS. 1, fol. 220r). Photo: Prof. Lorenzo Arias Páramo.

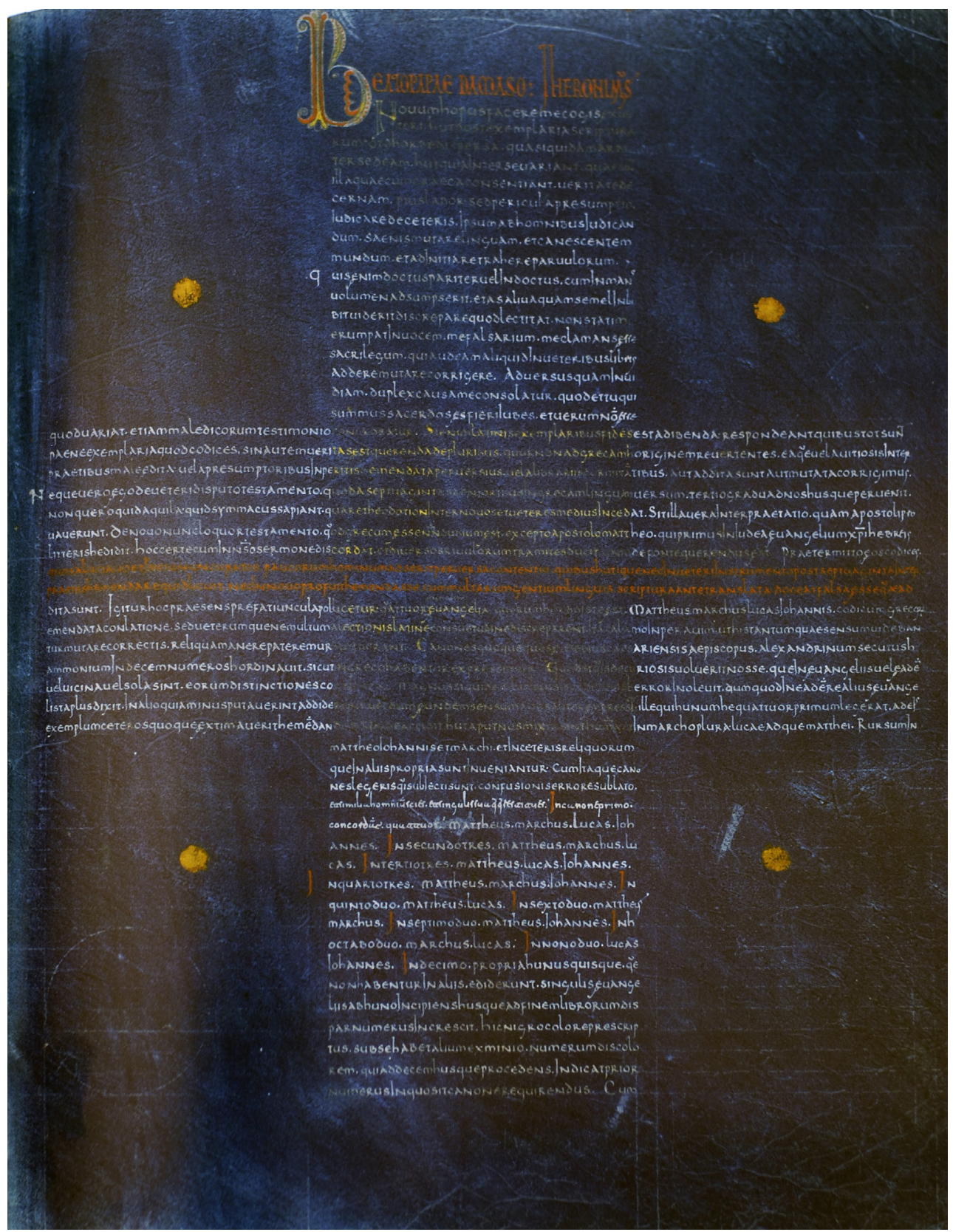




\section{Bibliografía citada}

Ager, Barry, "Byzantine influences on Visigothic jewellery", Intelligible Beauty: Recent research on Byzantine jewellery, Chris Entwistle, Noël Adams (eds.), ed. British Museum, London, 2010, pp. 72-82.

Aguirre CAno, Víctor, "La guerra entre el emirato de al-Andalus y el reino de Asturias durante el reinado de Alfonso II (791-842)", Boletín del Real Instituto de Estudios Asturianos, 63 (2009), pp. 181-254.

Anderson, Glaire, "Sign of the Cross: contexts for the ivory Cross of San Millán de la Cogolla”, Journal of Medieval Iberian Studies, 6 (2014), pp. 15-41.

Araujo-Costa, Luís, "La literatura en tiempo de Alfonso II el Casto", Estudios sobre la monarquía asturiana (Colección de trabajos realizados con motivo del XI centenario de Alfonso II el Casto, celebrado en 1942), Antonio Ballesteros (dir.), ed. Real Instituto de Estudios Asturiano, Oviedo, 1949, pp. 363-416.

Arias Paramo, Lorenzo, La pintura mural en el reino de Asturias en los siglos $I X$ y X, ed. Librería Cervantes. Oviedo, 1999.

Arias PARAmo, Lorenzo, "Aproximación a la realidad material del monacato asturiano en la Alta Edad Media", Monjes y monasterios hispanos en la Alta Edad Media, José Angel García Cortázar, Ramón Teja (eds.), ed. Fundación Santa María la Real. Centro de Estudios del Románico, Aguilar de Campoo, 2006, pp. 205-228.

Arias Paramo, Lorenzo, "Procedencia original de las jambas de San Miguel de Liño. Reutilización de decoración escultórica de Santa María del Naranco", Territorio, sociedad y poder, 5 (2010), pp. 5-22.

Arias PARAmo, Lorenzo, "Iconografía del poder en el arte altomedieval asturiano" (siglo VIII-IX)", Le corti nell'Alto Medioevo, Settimane di Studio del Centro di Studi dell'Alto Medioevo, Spoleto, 24 $4^{\text {th }}-29^{\text {th }}$ of April, 2014, ed. CISAM, Spoleto, 2014, pp. 940-942.

Ayuso-Marazuela, Teófilo, La biblia visigótica de la Cava dei Tirreni, ed. CSIC, Madrid, 1956.

BAngo Torviso, Isidro, "El arte asturiano y el Imperio Carolingio", Actas del Simposio “Arte prerrománico y románico en Asturias”, ed. Cubera Villaviciosa, 1984, pp. 31-88. BAngo Torviso, Isidro, “Alfonso II y Santullano”, Actas de las II Jornadas sobre el arte prerrománico y románico en el norte de España. Villaviciosa, 1985, ed. Cubera, Villaviciosa, 1988, pp. 207-237.

BAngo Torviso, Isidro, "Los reyes y el arte durante la Alta Edad Media: Leovigildo, Alfonso II y el arte oficial", Lecturas en Historia del arte (Ephialte), 4 (1992), pp. 17-32. BAngo Torviso, Isidro, "La cultura artística de la monarquía astur: la última manifestación de la Antigüedad, Astures. Pueblos y culturas en la frontera del Imperio Romano, Isidro Bango Torviso (ed.), ed. Asociación Astures: Gran Enciclopedia Asturiana, Gijón, 1995, pp. 183-186. 
BANGo ToRviso, Isidro "Las imágenes en los templos medievales. Del aniconismo a la intención docente: las tres posturas tradicionales de la Iglesia", La enseñanza en la Edad Media, José Ignacio de la Iglesia Duarte (ed.), ed. Instituto de Estudios Riojanos, Logroño, 2000, pp. 357-382.

BARrau-Dihigo, Louis, Historia política del reino asturiano (718-910), ed. Cañada, Gijon, 1989.

Barroso Cabrera, Rafael and Morin de Pablos, Jorge, Regia Sedes Toletana. El Toledo Visigodo a través de su escultura monumental, ed. Real Fundación de Toledo, Toledo, 2007, pp. 84-97.

Bischoff, Bernard, "Kreuz und Buch im Frühmittelalter und in den ersten Jahrhundernten der spanischen Reconquista", Bibliotheca docet. Festgabe für Carl Wehner, Joost Siegfried (ed.), ed. Erasmus Buchhandlung, Amsterdam, 1963, pp. 16-34.

BLoom, Jonathan, “The Blue Qu'ran revisited”, Journal of Islamic Manuscripts, 6.2-3 (2015), pp. 196-218.

Caballero Zoreda, Luís, "La iglesia de San Pedro de la Nave (Zamora): arqueología y arquitectura", Archivo Español de Arqueología, 70 (1997), pp. 221-274.

Caballero Zoreda, Luís and Feijoo Martinez, Santiago, "La iglesia altomedieval de San Juan Bautista en Baños de Cerrato (Palencia), Archivo Español de Arqueología, 71 (1998), pp. 181-242.

CABrera, Emilio, "Musulmanes y cristianos en al-Andalus: problemas de convivencia", Antigüedad Cristiana, 28 (2011), pp. 119-133.

Chazelle, Celia, The Crucified God in the Carolingian era, ed. Cambridge University Press, Cambridge, 2001.

Cherubini, Paolo, "La Biblia di Danila: un monumento trionfale per Alfonso II di Asturie", Scrittura e Civiltà, 23 (1986), pp. 75-131.

Cherubini, Paolo, Valdes Gallego, José Antonio and Garcia Leal, Alfonso, La Biblia de Danila (Codex Biblicus, Ms. 1 de la abadía de la Santísima Trinidad de Cava dei Tirreni), ed. GEA, Oviedo, 2010.

Cid Priego, Carlos, “¿Existió miniatura prerrománica asturiana?”, Liño, 1 (1980), pp. 107-142.

Cid Priego, Carlos, "La joyas prerrómanicas de la Cámara Santa de la Catedral de Oviedo", Liño, 10 (1991), pp. 7-46.

Cruz Villalón, María and Cerrillo Martin de Cáceres, Enrique, "La iconografía arquitectónica desde la Antigüedad a la época visigoda: ábsides, nichos, veneras y arcos", Anas, 1 (1988), pp. 187-204.

Colnins, Roger, The Arab conquest of Spain, 711-797, ed. Blackwell, Oxford, 1989.

Conant, Kenneth, Carolingian and Romanesque Architecture, ed. Yale University Press, New Haven, 1992. 
Cutler, Anthony, "Ivory working in Umayyad Cordoba: techniques and implications", The ivories of Muslim Spain, Kjeld von Folsach and Joachim Meyer (eds.), ed. The David Collection, Copenhagen, 2005, pp. 36-47.

Defourneaux, Marcellin, "Charlemagne et la monarchie asturienne", Mélanges d'histoire du Moyen Âge dediés à la mémoire de Louis Halphen, Robert-Henri Bautier (ed.), ed. Presses Universitaires de France, Paris, 1951, pp. 177-184.

Denoël, Charlotte, Roger Puyo, Patricia, Brunet, Anne-Marie and Poulain-Siloe, Nathalie, "Illuminating the Carolingian era: New discoveries as a result of scientific analyses", Heritage Science, 6:28, 2018 (https://doi.org/10.1186/s40494-018-0194-1).

DiAz y DiAz, Manuel, Asturias en el siglo VIII. La cultura literaria, ed. Sueve, Oviedo, 2001.

Dodds, Jerrilynn (dir.), The Art of Medieval Spain, A.D. 500-1200 (Catalogue of the homonym exhibition held at the Metropolitan Museum of Art, November 18, 1993 March 13, 1994), ed. Metropolitan Museum of Art, New York, 1993.

Dodwell, Charles, The pictorial arts of the West, 800-1200, ed. Yale University Press, New Haven, 1993.

FAVARQue, Bertrand, "La crois des Asturies: une signification escathologique?", Famille, violence et christianisation au Moyen Âge. Mélanges offerts à Michel Rouche, Martin Aurell, Thomas Deswarte (eds.), ed. Presses de 1'Université de Paris-Sorbonne, Paris, 2005, pp. 309-318.

Fernandez Conde, Francisco Javier and Pedregal Montes, María Antonia, "Santo Adriano de Tuñón: historia de un territorio en los siglos de transición", Asturiensia Medievalia, 8, (1995-1996), pp. 79-110.

Javier Fernandez Conde, Francisco Javier, "Cristianización y simbología del poder en la época de la monarquía asturiana”, La época de la monarquía asturiana, María Cruz Morales Saro (ed.), ed. Real Instituto de Estudios Asturianos, Oviedo, 2002, pp. 263-294.

Fernandez Conde, Francisco Javier, "El papel de la monarquía en la consolidación señorial del obispo de Oviedo", Studia Historica, 25 (2007), pp. 67-87.

Fernandez Conde, Francisco Javier, "La religiosidad medieval y las donaciones a la Iglesia", Las donaciones piadosas en el mundo medieval, Alfonso García Leal, ed. Universidad de Oviedo, Oviedo, 2012, pp. 9-58.

Fontaine, Jacques, L'art prérroman hispanique, vol. 2, ed. Zodiaque, Paris, 1977.

FonTAINE, Jacques "Mozarabie hispanique et monde carolingien (Les échanges culturels entre la France et l'Espagne du VIIIe au Xe siècle)", Anuario de Estudios Medievales, 13 (1983), pp. 17-46.

Garcia de Castro Valdes, César, Signum salutis: cruces de orfebrería de los siglos $V$ al XII, ed. KRK, Oviedo, 2008.

Garcia Rodriguez, Carmen, El culto a los santos en la España visigoda, ed. CSIC, Madrid, 1996. 
Garcia Moreno, Luís Agustín, Historia de la España visigoda, ed. Cátedra, Madrid, 2008. George, Alain, "Calligraphy, colour, and light in the Blue Qu'ran”, Journal of Qu'ranic Studies, 11.1 (2009), pp. 75-125.

GLick, Thomas, Cristianos y musulmanes en la España medieval (711-1250), ed. Alianza, Madrid, 2000.

GonZalez Garcia, Alberto "La proyección europea del reino de Asturias: Política, cultura y economía (718-910)", El Futuro del Pasado, 5 (2014), pp. 225-298.

Guilmain, Jacques, "Zoomorphic decoration and the problem of the sources of Mozarabic illumination", Speculum, 35, (1960), pp. 17-38.

Gwynn, David, "From Iconoclasm to Aranism: the construction of Christian tradition in the Iconoclast controversy", Greek, Roman, and Byzantine Studies, 47 (2007), pp. 225-251. Harris, Julie, "Muslim ivories in Christian hands: the Leire casket in context", Art History, 18/2 (1995), pp. 213-221.

JENSEN, Robin, Understanding Early Christian art, ed. Routledge, Abingdon, 2000.

KELLER, Adrian, "Le système espagnol de réglure dans les manuscrits visigothiques", Actas del $8^{\circ}$ coloquio del Comité Internacional de Paleografía Latina (Madrid-Toledo, 29 de Septiembre - 1 de Octubre, 1987), Madrid, 1990, pp. 107-114.

KenYon, Frederic, "Book divisions in Greek and Latin literature", William Warner Bishop: A tribute, Harry Miller Lydenberg, Andrew Keogh (eds.), ed. Yale University Press, New Haven, 1941, pp. 63-75.

Kitzinger, Beatrice, "Representing the Gospels beyond the Carolingian center", Imago libri. Représentantions carolingiennes du livre, C. Denoël, A.-O. Poilpré, and S. Shimahara (eds.), ed. Brepols, Turnhout, 2018, pp. 151-161.

LAFFITTE, Marie-Pierre and DenoËL, Charlotte, Trésors carolingiens: Livres manuscrits de Charlemagne à Charles le Chauve, ed. Bibliothèque Nationale de France, Paris, 2007. Lore, Vito, Monasteri, principi, aristocrazie. La Trinità di Cava nel secoli XI e XII, ed. CISAM, Spoleto, 2008.

Lowe, A., Palaeographical Papers 1907-1965, vol. I, ed. Clarendon Press, Oxford, 1972. Mansilla, Demetrio, "La supuesta metrópoli de Oviedo", Hispania Sacra, 8 (1955), pp. 259-274.

Martinez Diez, Gonzalo, Legislación conciliar del reino Astur (718-910) y del reino de León (910-1230), ed. Universidad de León, León, 2009.

Mateo Seco, Lucas, “Adopcionismo hispánico y el concilio de Frankfurt”, Anales Valentinos, 20 (1994), pp. 99-120.

McWilliam, Joanne, "The context of Spanish adoptionism: a review", Conversion and continuity. Indigenous Christian communities in Islamic lands eigth to eigthteen centuries, Michael Gervers, Ramzi Jibran Bikhazi (eds.), ed. Toronto University Press, Toronto, 1990, pp. 75-88. 
Noack-Halley, Sabine, "Tradición e innovación en la decoración plástica de los edificios reales asturianos", Proceedings of the "III Congreso de Arqueología Medieval Española”, Oviedo, March 27 - April 1, 1989, Oviedo, 1992, pp. 174-184.

Noble, Thomas, Images, Iconoclasm and the Carolingians, ed. Pennsylvania State University Press, Philadelphia, 2009.

Nordenfalk, Carl, Die Spätantiken Kanontafeln, Kunstgeschichtliche Studien über die eusebianische Evangelien-Konkordanz in der vier ersten Jahrhunderten ihrer Geschichte, ed. O. Isacsons, Gothenburg, 1938, pp. 57-64.

Nordenfalk, Carl, "The Eusebian Canon-Tables: some textual problems", The Journal of Theological Studies, 35 (1984), pp. 96-104.

Palazzo, Eric, “L'illustration dans l'évangéliaire au Haut Moyen Âge”, La Maison Dieu, 176 (1989), pp. 67-80.

Riche, Pierre, "Les refugiés wisigoths dans le monde caroligien", L'Europe héritière de l'Espagne wisigothique, Jacques Fontaine, Christine Pellistrandi (eds.), ed. CNRS, Paris, 1992, pp. 177-183.

Ripoll Lopez, Gisela, "Visigothic jewellery of the sixth and seventh centuries", From Attila to Charlemagne. Arts of the Early Medieval period in the Metropolitan Museum of Art, Katherine Reynolds Brown, Dafydd Kidd, Charles Little (eds.), ed. Yale University Press, New Haven-New York, 2000, pp. 188-203.

Rodríguez DíAz, Elena, "La industria del libro manuscrito en Castilla: fabricantes y vendedores de pergamino (ss. XII-XV)", Historia, Instituciones y Documentos, 28 (2001), pp. 313-351.

RodríGuez DíAz, Elena, "Manuscritos mozárabes: una encrucijada de tradiciones", Die Mozaraber. Definitionem und Perspektiven der Forschung, Klaus Herbers and Matthias Maser (eds.), ed. Lit Verlag, Münster, 2011, pp. 75-103, at 91.

Rodríguez Peinado, Laura, "Púrpura. Materialidad y simbolismo en la Edad Media", Anales de Historia del Arte, 24 (2014), pp. 471-495.

Rosenbaum, Elisabeth, "The Vine colums of Old St Peter's in Carolingian Canon Tables", Journal of the Warburg and Courtauld Institutes, 18 (1955), pp. 1-15.

Rotili, Mario, La miniatura de la Badia di Cava. II. Le racolte di miniature italiane e straniere, ed. Di Mauro, Naples, 1977.

Ruiz de la Peña Solar, José Ignacio, La monarquía asturiana (718-910), ed. Ayuntamiento de Cangas de Onís, Cangas de Onis, 2000.

Schlunk, Helmut, "Observaciones entorno al problema de la miniatura visigoda", Archivo Español de Arte, 71 (1945), pp. 241-265.

SchlunK, Helmut, "Crosses of Oviedo. A contribution to the history of Jewellery in northern Spain in the ninth and tenth centuries", Art Bulletin, 32 (1950), pp. 91-114.

Schlunk, Helmut and Berenguer, Magin, La pintura mural asturiana de los siglos IX y X, ed. L. Sánchez Cuesta, Oviedo, 1957. 
Schlunk, Helmut, Las cruces de Oviedo. El culto a la Vera Cruz en el reino asturiano, ed. Instituto de Estudios Asturianos, Oviedo, 1985.

SteENBock, Frauke, "Kreuzförmige Typen frühmittelalterlicher Prachteinbände", Das erste Jahrtausend: Kultur und Kunst im werdenden Abendland an Rhein und Ruhr, vol. 1, Victor Elbern (ed.), ed. Schwann, Düsseldorf, 1962, pp. 495-513.

Torrente Fernandez, María Isabel, "Sedes regias de la monarquía asturiana", Historia social. Pensamiento historiográfico y Edad Media. Homenaje al Prof. Abilio Barbero de Aguilera, Maria Isabel Loring García (ed.), ed. Del Orto, Madrid, 1987, pp. 575-591. Torrente Fernandez, María Isabel, "La corte de Oviedo", Orígenes, arte y cultura en Asturias: siglos VII-XV, María Cruz Morales Saro (ed.), ed. Lunwerg, Madrid, 1993, pp. 115-119.

URIA Riu, Juan, "Notas para el estudio del Mozarabismo en Asturias", Revista de la Universidad de Oviedo, 8 (1947), pp. 5-23.

VAzquez de PArga, Luís, "La Biblia en el reino Astur-leonés", La Bibbia nell'alto medioevo, Ezio Franceschini (ed.), ed. CISAM, Spoleto, 1963, pp. 257-280.

Vieillard-Troiekouroff, May, "Les bibles de Théodulphe et la Bible wisigothique de Cava dei Tirreni”, Synthronon. Art et Archéologie de la fin de l'Antiquité et du Moyen Âge, André Grabar (ed.), ed. Librairie C. Klincksieck, Paris, 1968, pp. 153-166.

VIVEs, José, Concilios visigóticos e hispano-romanos, ed. CSIC, Madrid, 1993. 
